Fecha de recepción: diciembre 2017

Fecha de aceptación: marzo 2018

Versión final: julio 2019

\section{Sombrero Vueltiao: Transformaciones de un objeto artesanal}

Paola Trocha*

Resumen: El sombrero vueltiao (símbolo cultural de Colombia) ha suscitado investigaciones a nivel etnográfico y antropológico que describen las manifestaciones sociales y culturales de la etnia Zenú. Este trabajo pretende acrecentar los estudios acerca de la producción artesanal desde la perspectiva de los flujos culturales y el dinamismo constante de la actualidad que condicionan e influencian las transformaciones en las artesanías que se producen. El análisis de estas consideraciones, entendidas como parte de procesos y transiciones sociales dinámicas, intenta estudiar un recorrido de las variaciones del sombrero vueltiao en respuesta a los diferentes contextos, que han impactado en sus modos de producción, consumo, significación y supervivencia.

Palabras clave: Campo social - Pueblos originarios - Sistema socio-técnico - Producción Artesanal - Sombrero Vueltiao - Posmodernidad - Hiperconsumo - Sostenibilidad - Diseño para la transición - Colombia.

[Resúmenes en inglés y portugués en las páginas 219-220]

(*) Paola Trocha es Diseñadora Industrial egresada de la Universidad del Norte (Barranquilla, Colombia) y Magíster en Gestión del Diseño, Universidad de Palermo (Buenos Aires, Argentina) Tesis de Honor. Asistente Académica del Seminario de Metodología de la Investigación, Maestría en Gestión del Diseño de la misma Universidad desde el año 2017. Ha participado en coloquios de investigación y publicaciones. Posee experiencia profesional y laboral en el diseño y desarrollo de productos desde sus distintos escenarios (material, transformación, comunicación y consumo). Ha forjado la capacidad de investigar y recopilar información para ser analizada y canalizada en posibles estrategias de innovación bajo los lineamientos del Design Thinking y el Diseño Estratégico. Investiga en el campo de Diseño con el propósito de ampliar las reflexiones en torno a la compleja relación entre el Diseño y la Artesanía. 


\section{Introducción}

Numerosas investigaciones conforman el compilado de estudios realizados por distintas fuentes sobre la etnia Zenú, asentada en el departamento de Córdoba en Colombia. Tales estudios han sido enmarcados bajo los lineamientos de ciencias como la antropología, sociología, psicología (específicamente del trabajo), entre otras; lo que da cuenta de la complejidad que ha implicado aproximarse y analizar esta cultura. Puche Villadiego (ingeniero civil de profesión, pero antropólogo y sociólogo por convicción) aportó más de 200 investigaciones de la cultura Zenú, entre ellas, El gran imperio Zenú. Centro de ingenieros hidráulicos y orfebres de filigrana fina en la América prehispánica, que como ésta se encuentran otros estudios significativos dentro del análisis de antecedentes históricos, costumbres, tradiciones, religión, fiestas populares y producción artesanal que lo convierte en uno de los principales investigadores de las culturas cordobesas.

Dentro de las investigaciones que estudian las producciones artesanales, se abordan cuestiones descriptivas como las técnicas originarias, procesos productivos, la división del trabajo, etc., mientras que autores como Rotman (2007), sitúan la investigación de la producción artesanal dentro de un marco global, es decir analizando la introducción de los productos artesanales dentro del mercado capitalista. El énfasis de estos estudios se centra en los procesos que orientan a la producción, y no tanto los objetos artesanales (Rotman, 2007:41), asunto que constituye el foco de atención de este trabajo, siendo que a través del sombrero vueltiao, se pretende dilucidar un recorrido de las transformaciones de este objeto a nivel proyectual y productivo; enfatizando que, como todo objeto es producto del devenir de una producción, en este caso manual, que para no desaparecer, ha debido incursionar y responder a los parámetros y exigencias del sistema capitalista.

En este sentido, el propósito se centra en analizar el posicionamiento que ha adquirido esta artesanía, cuyas modificaciones, a lo largo de los años, han cobrado justificación no solo según aspectos sociales, económicos y ambientales que lo han forzado a convertirse en un producto semi-industrial, sino a otros de tipo sociocultural relacionados con conservar el valor de la tradición y el apoyo establecido a las comunidades indígenas originarias.

De este modo los ejes de la presente reflexión, se inician con el pasaje de las transformaciones productivas a partir de las valoraciones proyectuales de las artesanías en relación con el arte y el diseño. Allí, se estudian las divergencias y convergencias entre las partes desde la perspectiva de sus respectivos campos, no sin antes contextualizar el valor simbólico y cultural que este sombrero representa hasta hoy para Colombia. Luego, considerando que las piezas artesanales se siguen concibiendo bajo las técnicas tradicionales originarias gestadas por los zenúes, de igual manera han sido afectadas por los cambios del entorno al que pertenecen, y sus variaciones se fundamentan solo para dar respuesta a la irrupción de los tiempos posmodernos (Bauman, 2002). La primacía de los medios de comunicación, los avances tecnológicos y la instauración de un modelo de sociedad postradicional han condicionado a las producciones artesanales, enlazándolas a través de una red de problemas intricados o wicked problems (Irwin, 2012, 2014,2017), en el que se involucran cuestiones sociales, ambientales y económicas, siendo que las exigencias de estos contextos han venido poniendo en situación de riesgo la supervivencia de las comunidades indígenas, sus 
sistemas productivos, la circulación de sus productos (base de las economías regionales) y sus tradiciones base de la identidad de la región.

Estos núcleos problemáticos vienen implicando mayor exigencia y compromiso en el trabajo con la comunidad artesana, del que se deriva un planteamiento que centra al Diseño como recurso activo en la búsqueda de la innovación social, de este modo no solo se valida su acción proyectual de conceptualizar, crear, inspirar o reproducir objetos, sino que se evidencia al diseño en el rol de catalizador de procesos para el cambio social. Se describen también algunas de las estrategias ideadas por Instituciones de apoyo al sector artesanal que, junto con las iniciativas de Diseñadores y distintos Profesionales, vienen contribuyendo al mejoramiento de la calidad de vida de las comunidades del pueblo Zenú.

El motivo de este análisis acerca de los cambios a nivel de proceso productivo de un producto artesanal específico, ayuda a comprender y a justificar cada una de sus modificaciones en un contexto histórico determinado, cuya influencia ha impactado en sus modos de producción y de significación. Desde esta perspectiva, el análisis de las transformaciones que ha tenido el sombrero vueltiao podría servir como guía para estudiar cualquier otro objeto artesanal bajo el enfoque de las distintas temáticas abordadas en este trabajo. De esta manera, se ha intentado estructurar un recorrido cronológico de sus modificaciones a través del tiempo, permitiendo conocer algunos de los parámetros que las motivaron en los inicios (premodernidad), luego en la etapa industrial (modernidad) y cuáles son aquellos que aún siguen modificándolo hasta la actualidad (posmodernidad).

A partir de este camino, y utilizando parte de las motivaciones temáticas que orientaron el trabajo de tesis de Maestría en Gestión de Diseño, de quién escribe ${ }^{1}$, y que guardan relación con este producto (sombrero vueltiao) y la etnia Zenú, se pretende abrir un espacio de reflexión que vincule algunas nociones aprendidas en relación con el Diseño para la Transición (Irwin et al, 2015) y cómo desde el diseño se pueden ofrecer soluciones vinculadas con la gestión que incidan sobre el sistema cultural, orientadas a promover cambios beneficiosos frente a la problemáticas que se describen en esta monografía.

\section{El caso del Sombrero Vueltiao. La etnia Zenú y la colonización española}

Los zenúes son el tercer grupo indígena más numeroso de Colombia (DANE, 2005²). Están asentados principalmente en la región de las sabanas del Caribe colombiano entre los departamentos de Córdoba y Sucre, donde la mayor parte de la población vive en zonas rurales, como los municipios de San Andrés de Sotavento, Tuchín, Sampués, Chinú, Sincelejo, y Palmito (Ver Figura 1).

En el trabajo etnológico realizado por Jaramillo y Turbay, las autoras sostienen, a través de estudios históricos, que el territorio ancestral de los zenúes (siglo XVI) se encontraba dividido en tres grandes provincias: Finzenú, dedicada al tejido y la cestería; Panzenú, dedicada a la producción de alimentos; y Zenufana, dedicada a alfarería y orfebrería, las que mantenían un constante y vital intercambio económico (Jaramillo y Turbay, 2000). El poblamiento de esta parte del Caribe colombiano se inició hace más de 4.000 años. Los zenúes moldearon la que hasta ahora es una de las más antiguas cerámicas conocidas en América y combinaban la explotación de la pesca y la caza con la agricultura intensiva de 
tubérculos. Por otra parte, la orfebrería y la alfarería también formaban parte de sus actividades, registrando un destacado desarrollo, siendo muy reconocidos sus adornos hechos en oro fundido. La técnica semifiligrana fue el rasgo característico de la decoración de la orfebrería Zenú, por lo general sus adornos que representaban animales de su entorno y elementos de su propia cultura.

Las investigaciones arqueológicas realizadas por Plazas, Falchetti, Van Der Hammen y Botero (1988), revelaron que los antecesores de los indígenas zenúes, construyeron una red de canales durante 2000 años, que les permitió controlar el medio lacustre y ribereño de las zonas circundantes al río San Jorge (Plazas et.al, 1988: 55; (Larraín, 2000:2). El sistema de canales se mantuvo y fue reacondicionándose conforme el paso del tiempo, favoreciendo su distribución funcional a lo largo de grandes extensiones de terrenos habitados por las tribus. Esta tecnología de irrigación para el direccionamiento de las aguas propició cambios ambientales en el bajo río San Jorge, sin embargo, la mecánica de utilización y modificación de los recursos naturales se fundamentaba en la eficiencia, es decir, menos recursos para un mismo objetivo.

Los canales cortos conforman un sistema eficaz para habilitar grandes extensiones de terreno para la agricultura. Las aguas de creciente eran llevadas con rapidez a las zonas bajas a través de canales largos y frenadas por los canales cortos, aumentando así el depósito de sedimentos en las zanjas y obteniendo una reserva de humedad para el verano. Estos sedimentos, extraídos de las zanjas, colocados en la parte superior del camellón, actuaron como fertilizantes de los cultivos (Plazas et.al, 1988:73).

Esta modalidad de trabajo descripta se corresponde con el manejo sostenible de los recursos, debido a que aprovechaban la riqueza de la región y la fertilidad de los suelos optimizándolos para llevar a cabo sus actividades, sin agresión ni depredación. Tanto la orfebrería, la cerámica y la utilización de los canales de irrigación desaparecieron conforme se fue instaurando el régimen de la Corona Española. Según Berdugo Palma (2009), la primera expedición realizada por los españoles a los territorios Zenú fue comandada por Francisco de Becerra en el año de 1515, pero no fue entonces hasta la próxima expedición en 1534 donde, bajo la dirección de Pedro de Heredia, gobernador de Cartagena, se realizaron las insaciables búsquedas de oro y el saqueo constante de las sepulturas indígenas. El período colonial desencadenó graves consecuencias como el maltrato a los indígenas, el aumento de la tasa de mortalidad a causa de los trabajos pesados, el abandono de las tierras y la pronta escasez del oro (Berdugo, 2009:49). Estos sucesos produjeron una transformación del paisaje natural del territorio, por la utilización de otras técnicas de cultivo y la incineración de los montes para adecuar los terrenos para las actividades de agricultura de acuerdo a la nueva organización (Jaramillo y Turbay, 2000). En consecuencia, después de la conquista, los territorios cercanos a las ciudades tomadas por los españoles no solo habían sido asoladas y agredidas, sino que carecían de bosques por el crecimiento demográfico operado por los nuevos asentamientos. 
Antes de la conquista española, los indígenas americanos sólo conocían el trabajo comunitario, sin explotadores ni explotados. La tierra y sus productos eran de todos. Con la Conquista todo cambió. Los nativos que no morían en la guerra eran maltratados y obligados a trabajar, sin importar que fueran mujeres o niños. Para esto el español organizó varia formas de trabajo. Primero se inventó la mita, luego la encomienda y, finalmente, ante la escasez de mano de obra, instituyó la peor de todas, la esclavitud, inicialmente de los nativos; luego, de los negros africanos (Berdugo, 2009: 54).

La llegada de los españoles alteró en primera instancia las circunstancias sociopolíticas de los zenúes, ya que tanto su organización como comunidad indígena y sus oficios fueron cambiados por otros impuestos por la Corona Española. Es así como la alfarería, la cerámica y la orfebrería fueron actividades sustituidas por la ganadería, la agricultura y la minería, que acarrearon no solo consecuencias a nivel ambiental como lo explican Jaramillo y Turbay (2000), sino profundos cambios en los modos de trabajo de los indígenas. De este modo, el saber hacer ancestral se tornó vulnerable ante la imposición del régimen europeo que propició que algunas destrezas y algunos oficios desaparecieran, otros se reemplazaran, y/o en el mejor de los casos, algunos otros se mantuvieran. En el caso de los zenúes, todos los objetos artesanales provenientes de la alfarería y la orfebrería desaparecieron por los constantes saqueos a las tumbas indígenas, quiénes por ritual fúnebre enterraban a sus familiares con algunas piezas de oro. Por otra parte, el trabajo de los cultivos, la ganadería, la pesca y la incorporación de la minería pasaron de ser labores asalariadas bajo el esquema de "la mita" o pago de salario, a labores impuestas bajo la modalidad de "la encomienda" en donde se le debía obediencia al encomendero, o bajo la modalidad de la esclavitud. El cultivo de maíz, según Puche Villadiego (1981), propició un progreso tecnológico en cuanto a los sistemas de cultivo, ya que además de los cambios en las técnicas de tala y manejo de los bosques, las cosechas requerían de utensilios para manipularlas, transportarlas y conservarlas, con lo que adoptaron nuevas fibras blandas y duras para la elaboración de cestos y canastos. Esto implicó nuevas variantes en los tejidos y en los utensilios que se usaban para la manipulación de los nuevos alimentos, por lo tanto fueron circunstancias que favorecieron el desarrollo de la tejeduría, oficio que aún permanece y representa, hasta la actualidad, la principal fuente de sustento del pueblo Zenú (Monserrate y Serano, 2016:6) $)^{3}$ : "Las costumbres sufrieron sustantivas modificaciones y ellas fueron soportadas a cambio de los beneficios por la llegada del maíz" (Puche Villadiego, 1981: 34-38).

El compilado de actividades descritas conforman las habilidades técnicas de los zenúes antes de la llegada de los españoles, que no necesariamente se encuentran ligadas a una tecnología material sino a los conocimientos y procedimientos que ellos, como comunidad, empleaban para desarrollar sus tareas. La construcción de canales para la irrigación de agua, la alfarería, la orfebrería, la tejeduría y el manejo de los cultivos fueron conocimientos técnicos de los zenúes en la época precolonial que fueron invadidos por los procesos impuestos por los españoles, asunto que condujo cambios a nivel social, técnico, ambiental y cultural. Algunos serán analizados intentando reflexionar sobre las intervenciones sucedidas en su sistema sociotécnico. 


\section{El sombrero vueltiao, su nacimiento y significación cultural}

Para Ortega y Gasset (1998), los motivos que han impulsado a los hombres en la creación de objetos han sido dos: el primero va dirigido a su utilidad o función para responder a una necesidad. Y el segundo se orienta a objetos de admiración con fines espirituales (Ortega y Gasset, 1998). En efecto, el sombrero vueltiao fue elaborado para cumplir con una función concreta: proteger la cabeza y el rostro de los campesinos de la intensidad solar, propia de los terrenos amplios y despejados de los cultivos de maíz. Su elaboración data más de 300 años, y en sus inicios su creación recae en las manos de las madres indígenas quiénes empezaron a tejer sombreros para sus hijos y esposos con un trenzado semejante a la de los canastos utilizados para la recolección del maíz con fibras extraídas de la planta Agave o mejor conocida como magüey, cuyas hojas son gruesas y resistentes. Luego, se adoptó la palma o caña flecha, cuyo nombre científico es Gyneryum Sagiitatum, la que debe ser pulida, asoleada, cocida, seleccionada y limpiada para ser apta en la fabricación del sombrero. En los comienzos, el sombrero tenía un diseño básico y monocolor, respondiendo a un fin útil (Ver Figura 2).

Sin embargo, con la implementación sobre las fibras, de procesos de teñido con recursos naturales, se logró dar contraste al diseño, y con ello la incorporación de las "pintas" a las trenzas que conforman el sombrero. Según se investigó el sombrero Zenú no es ninguna artesanía improvisada, ya que el diseño de cada "pinta" se debe a un trabajo de observación y de abstracción que realizaron los indígenas, resultado de un proceso histórico expresado en una habilidad artesanal. Los ríos que bañan sus tierras, el Cauca y el Sinú, están representados por la última trenza blanca y por la penúltima trenza en la que se mezclan tiras blancas y negras, respectivamente (Ver Figura 4). "Esta cultura ancestral, forjó en el trenzado su propio alfabeto de la memoria. Una historia graficada y contada del prodigio de los zenúes" (Tatis, 2013:6-7). Las "pintas" según los zenúes, son representaciones abstractas inspiradas en su entorno natural y en sucesos que han marcado la trayectoria de la comunidad, por ello cada pinta posee una fuerte carga simbólica para este pueblo del caribe colombiano (Ver Figura 3).

Con la inserción de las "pintas" surge la primera modificación del sombrero basandose en la exploración de elementos o características de su propia cultura, del ambiente, o incluso de las experiencias personales de sus hacedores. La flora, la fauna, la arquitectura, el vestuario, la gente, fueron fuentes de inspiración o "fuentes de diseño" que según Van Dommelen (1972) han sido válidas para estimular la creatividad del artesano. A esto Jorge Montaña (2010) lo denomina como "factor local" o "el estudio de las características propias de cada región (costumbres, cultura, clima, localización geográfica, etc.) para proyectar productos adecuados a esta realidad” (Montaña en Guzmán y García, 2010:42), que según el autor, una vez exaltados y trabajados los factores locales sobre los globales, generan un redescubrimiento que desemboca en sentimientos de orgullo y de pertenencia reconstruyendose en el producto artesanal su valor símbolo y en la comunidad un aumento gratificante de autoestima.

Es importante resaltar que el territorio Zenú goza de una ubicación estratégica ya que conecta el interior del país con el litoral, por lo tanto es y ha sido desde siempre una zona 
de mucha confluencia y tránsito que promovieron que la población fuese víctima de frecuentes ultrajes y despojos.

Debido a las formas de apropiación de la tierra derivada de las épocas coloniales y agravadas luego de las reformas de mediados del siglo XIX, las formas de apropiación monopólica y excluyente de la tierra se impusieron sobre esta estructura de la propiedad agraria, restringiendo el desarrollo de la mediana y la pequeña propiedad. Las grandes concesiones de tierras establecidas entre 1827 y 1931 y la expansión de las haciendas sobre los baldíos fueron generando un cerco sobre las tierras ocupadas por la pequeña y mediana propiedad. Limitadas por el agotamiento productivo, el crecimiento demográfico y los conflictos y ante las limitaciones del desarrollo económico del país, los campesinos debieron "saltar" dicho cerco e internarse en las colonizaciones más allá de las fronteras agrarias, [...] empujados por la guerra y por las "leyes para el destierro (Fajardo, 2014:6-7).

Más recientemente Cepeda y Rojas hacen referencia a la región Caribe como uno de los focos de surgimiento de grupos armados ilegales o paramilitares, como parte de la herencia de este conflicto histórico, y que:

Se originaron por la iniciativa de hacendados, terratenientes, ganaderos y hasta políticos buscando defender sus intereses sobre la tierra. Sus crímenes, masacres, métodos de tortura sanguinarios, persecución, asesinatos selectivos e implantación de terror en las poblaciones de la región, contribuyeron para el desplazamiento forzado de muchas personas y para la desocupación de territorios estratégicos que sirvieron y sirven a la expansión agrícola y ganadera (Cepeda y Rojas en Larraín, 2002:6).

Es así como la reducción de sus tierras se tradujo en la reducción del trabajo en los cultivos, aumentando el índice de desocupación, de tiempo libre, y con ello se hizo imperativa la búsqueda de otras fuentes de sustento económico para los indígenas. Esta situación permitió que la tejeduría cobrara fuerza y se acentuaran las confluencias entre los artesanos, que entre sus reuniones de atardeceres intercambiaban saberes e ideas iniciando la observación y exploración de su propio territorio, donde descubrieron otros recursos como el barro y hojas de algunos árboles, en el logro de tintes naturales que se comportaban bien con la caña flecha.

El valor otorgado a las artesanías se debe a su modo de elaboración, producción y a la carga cultural inherente de cada pieza. En cada región rural de Colombia se realiza alguna actividad artesanal que viste de colores y texturas al país, considerando el oficio como una labor que resalta las diversas tradiciones. Dando por sentado que los objetos son el resultado de materias transformadas con manos y herramientas que, por su connotación, se identifican bajo el término de arte o bajo el término de artesanía (Bovisio,2002) ${ }^{4}$, alrededor de estos objetos se han generado discusiones, acerca de sus valoraciones proyectuales en relación con el arte y el diseño. Esta distinción se naturaliza debido a la construcción 
histórica, social y cultural que se ha desarrollado a lo largo del tiempo, en aras de cimentar fundamentos distintivos entre las obras de arte y las artesanías. En efecto, hay una tradición jerárquica establecida entre las llamadas artes mayores y artes menores que proviene de la organización del marco institucional de las artes (Calvera, 2004), y cuya valoración ha incidido sobre las artesanías y la consecuente valoración del diseño, tal como sostiene Álvaro Zamora ${ }^{5}$ (1996)

Surge de la separación hecha por la crítica de arte en general entre lo "bello" y "lo útil", por lo que todo este segundo gran apartado del arte (artes menores), al presentar claramente esta faceta de utilidad (pues casi todas su manifestaciones tienen su uso concreto, aparte de la belleza) fue considerado un arte inferior (Álvaro Zamora, 1996:283).

Resulta evidente que las artesanías han sido continuamente menos valorizadas lo que ha implicado que sus vías de comercialización como su precio también lo fueran, de modo que, mientras que para una obra de arte su precio se calcula entre varios motivos: a través del prestigio del artista, si éste aún vive, la oferta y demanda de coleccionistas, etc.; para las artesanías su precio se basa en su costo de producción relacionado con el material, tiempo de trabajo, calidad, acabados y exclusividad (Bovisio, 2002:22-23). María Alba Bovisio (2002), indaga las tensiones que se generan en estos espacios de difusión, contactos, exclusiones y contaminaciones que se confrontan en el aspecto productivo con posturas de varios autores expresadas entre los años 1970 y 1990, pero los trabaja bajo el concepto de campo social desarrollado por Bourdieu. Desde esta perspectiva la autora define la oposición arte/artesanía como una "construcción cultural emanada de las prácticas concretas que ponen en circulación realidades materiales e inmateriales" (Bovisio, 2002:15).

Su postura permite diferenciar las distintas manifestaciones como prácticas concretas de determinados campos, donde cada campo tendría una estructura relacional entre los distintos agentes e instituciones que actúan en la producción, distribución y consumo, sean del campo del "arte" o del "artesanal". En este sentido, dentro del campo artesanal Zenú se han enmarcado distintos agentes, como artesanos, comerciantes e intermediarios (que actúan entre los dos primeros), y algunas instituciones como Artesanías de Colombia, Organizaciones No Gubernamentales (ONG) y el Instituto Colombiano de Normas Técnicas y Certificación (ICONTEC), que se convierten en garantes oficiales de la solución de las distintas problemáticas, sociales, culturales o productivas.

Retomando la postura de Bovisio (2002) que describe la dicotomía entre el arte/artesanía, se toma al sombrero vueltiao, como aquella realidad material producto de una práctica concreta realizada por los zenúes, que establece un eje central dentro del análisis de los objetos artesanales y su valoración de referencia vinculada al discurso o perspectiva de las artes. Es decir, la denominación del oficio artesanal como "arte menor" se torna difusa, ya que de ellas se construye sentidos de pertenencia e identidad, y más aún cuando algunas piezas artesanales, elaboradas por culturas indígenas son apreciadas y expuestas en museos como cualquier otra obra proveniente de las Bellas Artes. Según esta apreciación, García Canclini (1989) sostiene, 
Se demostró que en las cerámicas, los tejidos y retablos populares se puede encontrar tanta creatividad formal, generación de significados originales y ocasional autonomía respecto de las funciones prácticas como en el arte culto. Este reconocimiento ha dado entrada a ciertos artesanos y artistas populares en museos y galerías (García Canclini, 1989: 226).

Para García Canclini (1989), tanto antropólogos como folkloristas, que conforman parte de los agentes o instituciones del campo artesanal, son los que exaltan la producción de la cultura indígena, y son ellos mismos quienes tienen la facultad de elevarlas a otras categorías. En palabras de Dickie (1997), "las obras de arte son arte como resultado de la posición que ocupan dentro de un marco o contexto institucional” (Dickie, 1997:17), por tanto, el mundo del arte ${ }^{6}$ no tiene un sentido acotado, por el contrario, comprende una variedad de participantes y estructuras sociales. Para Dickie (1997), un artista siempre produce su obra dentro de un marco o un campo que lo rige, aun cuando no tenga contacto directo con las instituciones que la conforman, pero si guarda relación con los demás actores semejante a él (otros artistas/artesanos). Además de ellos y el público, hay otros participantes complementarios que desempeñan roles fundamentales para que algo se catalogue como arte: por un lado, productores y directores de museos; y por otro, periodistas y críticos expertos en el tema. Por último, un grupo conformado por historiadores del arte, antropólogos, teóricos, etc. Todos estos actores constituyen el campo sea del arte o artesanal, pero son ellos quienes confluyen para determinar cuándo una pieza se puede catalogar o no como arte (Bourdieu, 2002).

En el caso del sombrero vueltiao ocurrió un hecho interesante en relación a su significado. Antes del 8 de septiembre de 2004 (día que fue proclamado como símbolo cultural de la nación colombiana, Ley 908 decretada por el Congreso de la República, siendo el presidente del Senado, Germán Vargas Lleras) era asociado con la campesinidad ya que lo portaban personas propias de las zonas rurales como indígenas y campesinos quiénes lo llamaban sombrero indiano o sombrero de vueltas (25 de abril, 2016. Diario Universia). Después de su proclamación, el sombrero adquirió una nueva significación, ya que pasó de ser un objeto campesino a ser denominado símbolo cultural. Para el siglo XX el uso del sombrero vueltiao era común en fiestas populares, en el Carnaval de Barranquilla y en las corralejas, e incluso había sido incluido como parte del atuendo de los cumbiamberos, sin embargo, su categorización como símbolo cultural se debió a las consideraciones realizadas por agentes e instituciones pertenecientes al campo artesanal Zenú, quienes obtuvieron las facultades para elevarlo a la categoría de símbolo cultural nacional.

Campi (2004) sostiene que las distinciones o consideraciones artísticas de una cosa no sólo se deben a la actividad creadora, sino que depende en gran medida a la aceptación sociocultural que ésta alcance dentro de los actores del campo. En definitiva, el sombrero Zenú al representar una identidad de un país, posee desde los tiempos de su creación, cobrada aceptación por parte de sus habitantes, ya que este objeto artesanal habla de su pueblo, ya que lleva consigo la representación de una geografía, una cultura y una historia. Una geografía, porque fue concebido en los valles del río Sinú entre los departamentos de Córdoba y Sucre, que considera a su territorio ancestral como simple soporte estático de recursos naturales para su elaboración. Una cultura, donde todas las costumbres, tradi- 
ciones y técnicas ancestrales se traspasan manualmente en su fabricación. Y una historia, donde todo campesino, indígena, y colombiano ha portado sobre su cabeza el sombrero, significando toda una compilación de acontecimientos históricos. El sombrero vueltiao sigue presente en las distintas protestas políticas actuales, que se realizan en las ciudades principales del país, donde si bien las personas llevan banderas y símbolos patrios, también llevan su sombrero como parte de su identidad. Estas características de inspiración tradicional enmarcan al sombrero dentro de una comunidad específica que plasma su idiosincracia, sus técnicas ancestrales y tradicionales en cada artesanía.

Estas virtudes han otorgado al oficio artesanal Zenú la responsabilidad del repertorio de elementos de identificación y representación nacional frente a los demás países del mundo. Es decir, la adquisición de conocimientos a través de un objeto que revela, un territorio, una historia y una cultura que va más allá de la que ya se conoce.

\section{El sombrero Vueltiao. Artesanía y Diseño}

Para el siglo XVII, los oficios como la ebanistería, la cerámica, la tejeduría, etc. (llamadas artes menores) estaban muy desarrolladas y ofrecían productos con excelentes acabados y calidad. El buen nivel de estos objetos frutos del devenir de estos saberes, forjaron las bases para que en la segunda mitad del siglo XVIII, la técnica se transformara en tecnología, hecho que abrió las puertas hacia la revolución industrial en Inglaterra. A partir de allí el auge de la producción en serie no se hizo esperar, pero no fue entonces hasta la Gran Exposición Internacional (The Great Exhibition of the Works of lndustry of all Nations) realizada en 1851 en Londres, dónde se generaron cuestionamientos acerca del diseño de estos productos (Gay, 2007:33), las que dieron lugar a las incipientes disciplinas del Diseño Gráfico, Industrial, de Interiores, de indumentaria, etc. que cobraron cada vez mayor fuerza con el pasar de los años.

La revolución industrial fue un hecho que marcó un precedente en los modos de producción, se aumentó la cantidad de productos en menores tiempos de fabricación ya que se simplificaron las tareas complejas y detallistas propias de las artes menores, en procesos más simples y económicos, derivándose en un profundo cambio social y económico para todas aquellas personas que desempeñaran un oficio (Ricard en Calvera, 2004:90). Esta modificación de la mano de la tecnología fue un cambio socio-técnico ya que siguiendo las ideas de Roca (2011), alteró los modos de aprender, producir y organizarse como sociedad, un cambio que tuvo consecuencias relevantes en los modelos sociales.

Para el caso de las producciones artesanales indígenas, los efectos de este cambio sociotécnico se reflejaron de manera paulatina dentro de sus procesos productivos, ya que sus intereses, en un principio, se enfocaban en elaborar productos para autoconsumo y utilitarios para realizar sus labores, no obstante, tales intereses se hacían cada vez más semejantes a los establecidos por el mercado, pero al ser producciones elaboradas manualmente, no tenían competencia alguna (en costo) frente a una producción en serie.

Sobre el contexto de cotidianidad y la utilidad como pretexto inventivo de las artesanías, se cimientan las bases de lo que sería el papel del diseño en la era industrial, determinando los parámetros productivos y de estética a través de los lineamientos del good design. Esto 
marcó pautas de diseño enmarcadas dentro del racionalismo: la forma sigue a la función: "Un producto bien diseñado es aquel cuyas formas tiene una coherencia integradora en que nada les sobra ni les falta para cumplir la función asignada" (Ricard en Calvera, 2004: 92) Por su parte, Munari en la década del 70 veía al diseño industrial, específicamente, como una disciplina proyectual alejada del hecho del arte:

El diseñador, en cambio, no se dedica a piezas únicas ni tiene categorías artísticas en las que catalogar su producción. Para el diseñador no existen el arte puro y el arte aplicado. Cualquier problema, tanto si se trata de proyectar un vaso como un edificio residencial, tiene la misma importancia. El diseñador no tiene una visión personal del mundo, en sentido artístico, sino un método para afrontar los diversos problemas del proyectismo (Munari en Calvera, 2004:40).

Ambas apreciaciones, tanto la de Munari como la de Ricard, representantes históricos y de prestigio dentro del campo del diseño, se enmarcan dentro de la clasificación orientativa que distingue Calvera (2004) acerca de los diseñadores que conciben al diseño distinto del arte y que se inscriben como pertenecientes a la época fundacional de la disciplina del Diseño, evidenciando las pautas que se dictaminaron en el origen e interior del campo en su definición desde la mirada más tradicional.

Siguiendo estas definiciones si el campo artesanal, está atravesado por la utilidad en un contexto cotidiano y en el campo del diseño está la funcionalidad dentro de un contexto industrial, entonces, cabe preguntarse ¿cómo se ha realizado el pasaje de las artesanías, específicamente aquellas elaboradas por las comunidades indígenas hacia el campo del diseño, una vez instalada la revolución industrial? Sin duda ha tenido que pasar mucho tiempo para que las miradas provenientes del Diseño y los diseñadores entraran a apoyar a los grupos étnicos productores de artesanías. Es posible que esta convergencia se haya dado por dos razones: la primera, porque en el Diseño es necesaria la incorporación de pautas y prácticas relativas a la responsabilidad social y cultural como varios campos del diseño emergente vienen amplificando (Diseño para la transición, Irwin et al, 2015); y la segunda de acuerdo explica Anna Calvera, por la conversión de lo culturalmente "bello" en una estrategia económica (Calvera, 2004:24).

Chiapponi (1999) sostiene que la función principal del diseño es la proyección y la planificación de objetos materiales. Sin embargo, ésta profesión no puede olvidarse de su pertenencia a un mundo más amplio, que es parte de un contexto en cambio permanente. De allí la importancia de analizar "la situación actual, en la que profundas transformaciones tecnológicas, sociales, económicas, culturales y ambientales hacen necesaria una reflexión total acerca de la cultura material contemporánea" (Chiapponi, 1999: 10). De esta definición se deduce que el diseño tiene el mérito de ser flexible, adaptable en el tiempo y en contextos. Por tanto, no se puede categorizar a la profesión sólo por su capacidad de proyectar y planificar un determinado producto, también debe asumir que tiene la función y responsabilidad de integrar múltiples factores mutuamente interactuantes. Tal como expresa el Diseño para la Transición se hace necesaria la comprensión de la dinámica social en relación con el producto de diseño y para ello es necesario un diseño que actúe desde una mentalidad transdisciplinaria, es decir que esté 
Informado del conocimiento que proviene del exterior del diseño: la ciencia, la filosofía, la psicología, la ciencias sociales, la antropología y las humanidades, etc. con el fin de obtener una comprensión más profunda de cómo diseñar para el cambio de transición en los sistemas complejos (Irwin, et al,2015).

Es por ello, que el diseñador involucrado en el proceso de desarrollo, debe contar con el apoyo de todos los actores implicados (artesanos, entidades gubernamentales, organizaciones, etc.) para propiciar diálogos constantes, fortalecer los canales de comunicación entre ellos con el fin de obtener un conocimiento certero y profundo del diagnóstico de situación y de las gestiones que conduzcan a los objetivos planificados. Según esta noción, se podría considerar al Diseño como un recurso fundamental en el proceso de inserción de los productos artesanales, siendo que debe existir un proceso bilateral en las formas de hacer diseño, donde predomine el trabajo grupal entre diseñador/artesano, y que además, los aportes del diseño a la producción artesanal, a nivel de planificación, proyección y organización, deben contemplar la discusión y propuestas de todos los agentes que conforman el grupo de trabajo (diseñadores, artesanos, instituciones, etc.)

Mora (1974) sostiene que:

El diseño que viene de arriba hacia abajo tiene excelentes repercusiones: mejores ventas, mejor fuente de trabajo y más refinado gusto. Beneficia indiscutiblemente a la artesanía. El diseño que viene de abajo hacia arriba, el que es producido por cualquier persona que después de un entrenamiento ha sentido liberada su capacidad de expresión, beneficia más al artesano, que se sentirá entonces más realizado, en la medida que haya podido expresar más cabalmente sus concepciones. Así, con la enseñanza del diseño, el artesano no sólo podrá vender más y mejor, sino que estará menos angustiado, y más satisfecho con su obra. Se habrá logrado una verdadera terapéutica social que los alivie de innumerables tensiones psicológicas (Mora, 1974: 57).

Esta perspectiva plantea dos iniciativas de cómo se puede implementar el diseño: una mediante la asesoría, que la autora define como el "diseño que viene de arriba hacia abajo", y la otra mediante la enseñanza del diseño o "el diseño que viene de abajo hacia arriba". En ambos esquemas se hace imperativa una vinculación que parte desde la acción del diseño, visto como herramienta estratégica para mejorar el nivel de los productos artesanales mediante una iniciación o capacitación del artesano por parte de diseñadores, para que puedan desarrollar más y mejores habilidades y así acceder a una mayor autonomía en la elaboración de sus productos. Generalmente, estos trabajos se realizan bajo esquemas de módulos o talleres de diseño organizados por un equipo de profesionales conformado por diseñadores industriales y asesores de diseño, cuyo objetivo estratégico es posicionar a las artesanías en el mercado.

Para Chiapponi (1999) el campo de aplicación del diseño industrial si bien es vinculado generalmente con la manufactura de objetos producidos industrialmente, también mantiene relaciones con otras disciplinas proyectuales, como la ingeniería, y con otros campos de actividades afines, como la actividad artesanal (Chiapponi, 1999:17). En este sentido, 
se describe un trabajo donde interactúan personas (artesanos y diseñadores) que se valen de distintos medios para el desarrollo del sector artesanal. Estas iniciativas basadas en las nociones de los cambios de los sistemas sociotécnicos proponen distintas maneras de lograr la optimización conjunta basándose en un desarrollo organizacional que reconoce las relaciones complejas entre elementos sociales y técnicos que conducen a la productividad y bienestar (Wikipedia, recuperado el 18 de junio de 2017).

La relación del diseño con la actividad artesanal se puede considerar en parte competitiva y en parte cooperativa. La parte competitiva se circunscribe a la disputa histórica entre dos sistemas productivos: el industrial y el artesanal (Chiapponi, 1999:18). Anteriormente se exponía el vínculo directo al que se asocia la profesión con los objetos manufacturados industrialmente, el que lógicamente difiere con la concepción artesanal, pero más allá de eso, la divergencia radica en la división del trabajo del sistema de producción industrial. A diferencia del artesano, el diseñador industrial no finaliza él solo todo el proceso productivo, pero sí puede, y ésta sería la parte cooperativa de la relación, participar y apoyar la concepción y proyección de productos artesanales (Chiapponi: 1999: 18), aptitudes que aún no están fortalecidas en el artesanado y levemente esbozadas desde el diseño y las instituciones.

El diseñador industrial Rafael Barreto, miembro del equipo del Laboratorio de Diseño de Córdoba (Colombia), argumenta sobre la importancia del trabajo en conjunto con el artesano y cómo el diseño puede potenciar sus capacidades,

Ellos [los artesanos] se dan cuenta que sí les hace falta un acompañamiento en cuanto a diseño porque tienen una producción artesanal, en unos casos muy anticuada, pero es una producción al fin y al cabo... Y los conocimientos de uno como diseñador les ayuda a potenciar o impulsar ciertos puntos en los cuales ellos fallan (R. Barreto, extraído de una comunicación personal, el 30 de julio de 2016).

Este es un aspecto que destaca que el diseño puede ofrecer un diferencial a partir de la enseñanza y continua investigación de los materiales para la creación de nuevas artesanías de excelente calidad. También se ha hecho énfasis en lo fundamental que es mantener a los productos artesanales en constante renovación y evolución, de acuerdo al dinamismo cultural en que se encuentren. Sin embargo, no dejan de ser apreciaciones que se enmarcan dentro de un nivel proyectual, técnico y productivo.

Barrera y Quiñones (2006), desde su experiencia profesional y como diseñadoras industriales del grupo investigativo Diseño Socio-Cultural del departamento de Diseño de la Pontificia Universidad Javeriana, puntualizan el lado positivo y negativo de la intervención del Diseño dentro de la producción artesanal colombiana. Las autoras, manifiestan que la implementación del Diseño en la producción artesanal ha logrado potenciar el reconocimiento de la diversidad de producción artesanal del país, y que su plataforma de conocimiento ha aportado a la organización, diversificación y mejoramiento de los aspectos técnico-productivos del artesanado. Dentro de los puntos negativos, las autoras argumentan la falta de conocimiento del equipo de trabajo sobre la comunidad con la que les ha tocado trabajar e intervenir. Sostienen que dentro de los programas que lanza 
el gobierno para potenciar el sector artesanal no cuentan con estrategias integrales que direccionen los productos al mercado nacional e internacional, por lo tanto se hace más difícil para los artesanos acceder a ellos. En definitiva, cada una estas falencias identificadas excede al nivel técnico, proyectual y productivo en los que de momento trabaja normalmente un diseñador, esto indica que el análisis y el trabajo de los profesionales del Diseño deberían ser amplificados, para poder acceder a la gestión de aquellas problemáticas que resultan ser más complejas, con el fin de encontrar estrategias que conduzcan a soluciones concretas y precisas.

Particularmente la intervención y el trabajo del diseño con los artesanos Zenú se contemplaron desde una iniciativa a nivel nacional en apoyo al sector artesanal del país, bajo la gestión de Artesanías de Colombia, entidad gubernamental adscripta al Ministerio de Industria y Comercio, y al Ministerio de Turismo, cuya misión es contribuir al progreso del sector mediante el mejoramiento tecnológico, la investigación, el desarrollo de productos y la capacitación del recurso humano para impulsar la comercialización de artesanías (Fries, 2015:3). Desde sus comienzos en 1970, sus iniciativas fueron un tanto experimentales mientras se adquiría el conocimiento y el manejo del rubro. Luego de cinco décadas, algunas de estas intervenciones, con un grado mayor de madurez adquirida por la experiencia, continúan presentando estrategias o propuestas que se desvían de las problemáticas y/o necesidades de la comunidad. Como una de estas divergencias o falta de comunicación presente entre las partes (diseñador o institución/ artesano) que encabeza los listados de estos inconvenientes se encuentran la definición de los distintos programas de capacitación que se ofrecen a los indígenas y el alto índice de ausentismo una vez inscriptos. Isaac García como artesano Zenú y Rafael Barreto como diseñador que trabaja con los artesanos, exponen desde su posición distintos puntos de vista:

Como ya se ha descentralizado un poquito la labor de Artesanía de Colombia, [...] se disponen de unos enlaces en los departamentos que son responsables de las artesanías en ese departamento, y ese enlace se encarga de hacer un diagnóstico general sobre todo el tema artesanal en el territorio donde se identifican oficios, y todo lo referente a la artesanía y su estado actual a nivel social, municipal; en fin todo esto, y se plantea un proyecto. Es un tema de apoyo con las alcaldías y con todo esto, porque son todos ellos lo que hacen el puente con la comunidad, los que ayudan a gestionar todos estos espacios para que se pueda dar el taller o dar el proyecto en ese municipio. [...] Ese diagnóstico lo hace un diseñador, que los enlaces son también diseñadores y lo hacen con un coordinador, monitor o gestor; ya eso depende de un tema de contratación de la profesión que tenga, pero siempre se apoyan en las comunidades, en las alcaldías, secretarías de cultura, todo eso como para hacer la gestión en un principio, entonces ellos como que ya tienen un equipo que vienen trabajando años con ellos y que poseen mucha información al respecto (Rafael Barreto, extraído de una comunicación personal, 30 de julio de 2016).

Por su parte, Isaac García considera que las intervenciones a través de estos programas de capacitación realizados por Artesanías de Colombia son buenas, sin embargo manifiesta 
que se debe escuchar las necesidades expuestas por los mismos artesanos para plantear programas o estrategias que los intervengan.

Lo considero desde el punto de vista bueno, relativamente hablando. Bueno porque listo, ellos se interesan por nuestras necesidades, pero ¿qué pasa?, no son las necesidades socializadas o extraídas por nosotros los artesanos. Por el contrario, ellos son los que dicen qué curso dictar, por ejemplo, este año es de materia prima. Entonces ese no es el tema. El tema es que ellos se puedan reunir con los artesanos, y preguntarnos: muchachos, ¿Cuáles son las dificultades que ustedes tienen?, ¿Cuáles son las actividades o proyectos que les interesaría trabajar? Ósea ellos establecen la metodología de trabajo en el área que ellos escojan. Digamos que no es socializada, ni toman la consideración de los artesanos (I. García, extraído de una comunicación personal, 04 de junio de 2016).

Además se suma el alto nivel de ausentismo de los artesanos en asistir a las clases de capacitación,

Existe mucho apoyo pero el artesano es un poco reacio para asumir esa capacitación o ese conocimiento. Al momento de beneficiarse, por ejemplo, si vamos abrir un curso de nuevas técnicas de diseño e innovación de producto, los primeros dos días hay 100 artesanos, pero al final a la tercera, cuarta o quinta sesión ya van abandonando el curso. No se les nota aquel interés de querer avanzar técnicamente con el conocimiento, con ayudas profesionales, sino que se casaron con la técnica de ellos y así quieren ir desempeñándose (Isaac García, extraído de una comunicación personal, el 04 de junio de 2016).

Rafael Barreto, como diseñador, sostiene que es de vital importancia la manera en cómo se realiza el acercamiento al artesano,

Todo está en la manera en que se dicten los cursos, los medios que utilices para dictar esos cursos, la actitud con que tú llegas para dictar esos cursos, o sea, como eso no es una camisa de fuerza para nadie, va el que quiera, pero de todas forma nosotros tenemos una meta de beneficiarios que tenemos que cumplir, entonces también está en uno cautivarlos y motivarlos.[...] En un principio, tú tienes que acercarte a la comunidad más como visita de campo, proponer, ir casa por casa e ir a los talleres y [decir], mire mi nombre es tal, yo vengo de Artesanía de Colombia, estamos empezando un proceso, todo una "cháchara", invitándolos al proyecto y ya en reuniones y consenso con la comunidad se establece un día, se establece un horario. En esos casos también recurrimos a secretarías de cultura para que nos puedan apoyar para ver si nos facilitan un espacio y que no presten un salón o un aula y poner punto de reuniones (Rafael Barreto, extraído de una comunicación personal, 30 de julio de 2016). 
Tanto el acercamiento a la comunidad como mantener la motivación de los artesanos en finalizar los cursos de capacitación, son desafíos que debe superar un diseñador desarrollando habilidades y aptitudes que sólo se adquieren visitando y conociendo al territorio que se pretende intervenir. En virtud de maximizar y mejorar el papel del Diseñador como recurso humano que apoya a una comunidad artesana específica, Barrera y Quiñones (2006) sostienen que se debe realizar un análisis bajo el enfoque de la comunidad, así las decisiones a tomar y su direccionamiento se deben perfilar conforme a sus intereses. Manifiestan que para lograr una aproximación hacia y con la participación de una determinada población indígena, se debe contar con un previo conocimiento del sistema que estructura a la comunidad, tanto en dimensiones generales como costumbres, religión, gastronomía, fiestas populares; y en dimensiones específicas como transformaciones de materia prima, elaboración de productos, técnica, herramientas, modos de trabajo, estándares de calidad, acabados, distribución de productos, ventas, exhibición etc. Por último, plantean algunos elementos para que los distintos actores: artesanos, diseñadores y otros profesionales que conforman el equipo de trabajo, se relacionen como pares humanos, es decir, puedan hacer confluir entre ellos saberes, conocimientos, opiniones y virtudes como puntos de vistas de igual relevancia. De esta manera, "se reconoce la dimensión del otro, hace ver la necesidad de validar la mirada del artesano y tener en consideración su opinión y capacidad de decisión sobre la enseñanza que requiere y la orientación que necesita" (Barrera y Quiñones, 2006: 35).

Las anteriores pautas son consideraciones que se deben tener en cuenta antes de realizar cualquier intervención a una comunidad indígena, ya que cualquier acción afectaría directamente a sus costumbres y sistemas de valores, y tendría mayor repercusión negativa si los actores a involucrarse las desconocen. Por ello, antes de entablar cualquier mecanismo de acción se hace imperativo analizar a priori la manera de resolver las problemáticas no desde la posición de manipular, irrumpir o cambiar sus hábitos, valores o costumbres, sino desde una intervención que contemple posibilidades de recuperación o preservación para que las soluciones o estrategias tengan mayor afinidad y congruencia con la idiosincrasia de la población.

\section{Migrar hacia otro sistema de producción}

Para Bustos (2009) "un sistema de producción es un método, un procedimiento que desarrolla una organización para transformar recursos en bienes y servicios” (Bustos, 2009:37), es decir, que si una organización desarrolla un sistema de producción, éste se concibe bajo una mezcla de interconexiones entre personas, tecnologías y su entorno; es decir se gesta en un sistema sociotécnico particular. La condición intrínseca de un sistema sociotécnico de interacción entre personas, permite la confluencia de elementos sociales y culturales. En este sentido, tales confluencias derivan en nexos o relaciones constructivas que incitan el dinamismo y el cambio. Para Jackson (1995) el concepto de cultura debe ser abordado bajo una condición dinámica que se encuentra inmersa en un sistema donde se implantan cambios, que al final afianzan su construcción social (Jackson, 1995:20). 
Estas instancias no son ajenas a una producción artesanal, que aunque sea manual, se circunscribe dentro de un sistema de producción que lo establece un grupo de personas, que en su mayoría son artesanos: "La producción artesanal elabora objetos mediante la transformación de materias primas naturales básicas, a través de procesos de producción no industrial que involucran máquinas y herramientas simples con predominio del trabajo físico y mental" (Bustos, 2009:37).

Desde una perspectiva más antropológica, Jorge Fernández Chiti (2003), filósofo y antropólogo argentino, sostiene que la artesanía es el resultado de una

Actividad productiva y creativa de carácter plástico manual e inspiración tradicional; de concepción, confección y planificación seriada; que se materializa en objetos, obras o piezas que responden a una necesidad funcional o de uso cotidiano, decorativo, mágico, religioso, etc.; con un ingrediente estético o decorativo necesariamente presente; facturada en un taller doméstico o profesional reducido, sin procesos tercerizados; mediante técnicas manuales y no manuales pero nobles, genuinas y de control personal por parte del artesano; cuya producción es restringida y destinada a un mercado reducido, de ferias, $o$ comercial pero conocido por el artesano (Fernández Chiti, 2003: 25).

Esta definición es muy completa ya que abarca a la artesanía desde su concepción, modos de producción, hasta su contexto comercial. Es aquí donde el Diseño como disciplina debe reflexionar y entender los lineamientos inherentes a cualquier producción artesanal, para incorporar a sus metodologías de gestión, acciones que respondan a la naturaleza de este oficio y a sus problemáticas.

A partir de la década del 70, Artesanías de Colombia inició este acompañamiento con una serie de propuestas que consistieron en hacer el intento de pasar los productos artesanales del marco de la utilidad y/o del autoconsumo a insertarlos dentro de la estructura del sistema capitalista. Las gestiones entre la etnia Zenú con esta Institución se iniciaron diez años después de 1960, década que Scatolini (2011) señala como el punto de inflexión a partir del que sucedieron una lista de varios sucesos históricos, económicos, políticos y religiosos que fueron forjando el pasaje de la modernidad a la posmodernidad. Estos acontecimientos se iniciaron en Europa y Estados Unidos, por ello en América Latina los cambios se reflejaron unas décadas después. De allí, que los 90’s es considerada como la década de consolidación del mundo globalizado donde "la sociedad posindustrial se identifica con la sociedad de servicios o tercerizada, telematizada, construyendo una sociedad totalmente informatizada" (Scatolini, 2011:342-343).

Volviendo al sombrero vueltiao las estrategias para la etnia Zenú se iniciaron, según Fries (2016) con la indagación y conocimiento de las posibilidades de manejo que ofrecía la caña flecha en conjunto con varias pruebas experimentales de teñido utilizando distintas especies de plantas de la región.

El primer acercamiento de diseño se realizó mediante la identificación de las posibilidades de la materia prima, y en la versatilidad técnica que brinda el proceso de costura, lo que incursionó en el desarrollo de accesorios perso- 
nales, dentro de los que se destacaban bolsos, sombreros, pavas, etc., que han alcanzado buenos niveles de ventas en el mercado nacional con una propuesta de innovación importante en su momento. Años después el trabajo se centró, en la experimentación bidimensional y tridimensional con el material, lo que generó como resultado, nuevas propuestas en diferentes formatos, que ampliaron su línea de productos al área de mesa y decoración (tapetes, contenedores, individuales, centros de mesa, etc.). Ello generó un impacto positivo en los consumidores de artesanías (Fries, 2016: 7).

Parte de las ideas esbozadas en 1993 para instaurar el Laboratorio de Diseño para el Desarrollo de la Artesanía y la pequeña empresa, estuvieron fundamentadas, en gran medida, en dos estrategias: innovación y mejoramiento tecnológico para la inclusión de la producción artesanal al mercado, y la investigación y desarrollo de productos (Barrera y Quiñones, 2006:54), cuya formulación se dirigía a "contribuir al desarrollo del sector artesanal colombiano, elevando la competitividad del mismo con calidad, a través de procesos integrados en desarrollo de productos con innovación dirigidos hacia el mercado" (Artesanías de Colombia, 1998:9) entendiendo que competitividad, calidad, innovación y mercado son conceptos que sitúan a la producción artesanal dentro de los marcos capitalistas (Benedetti, 2014:22).

En definitiva, esta misión definida por Artesanías de Colombia demuestra su intención de instaurar, desde la década del 90, una política de diseño cimentada dentro de los lineamientos propios de la disciplina, como son la innovación de productos y desarrollo de tecnologías perfiladas hacia el progreso del sector artesanal en Colombia. Sobre este objetivo cargado de concepciones propias de la época, Barrera y Quiñones (2006) se preguntan por

Las formas de representación y expresión propias de las culturas en relación con la necesidad de adecuar el producto a las exigencias del mercado. ¿Acaso el mercado cuando busca un producto artesanal no está buscando aquellas representaciones, expresiones y connotaciones culturales propias del productor?, ¿acaso el mercado para productos artesanales no está buscando un vínculo con aquello que es y que esencia simbólicamente estos objetos?, ¿acaso no hay una necesidad en el mercado por significados de mundos paralelos y diversos, un deseo por encontrar y relacionarse con los mundos del productor que se vehiculan en la artesanía? (Barrera y Quiñones, 2006:54-55)

Estos cuestionamientos incitan a reflexionar si realmente estos procesos de planificación racional, dirigidos a las producciones artesanales, que implica un viraje hacia lo innovador, lo competitivo y lo comercial son los mecanismos de intervención adecuados para trabajar con este tipo de sistemas productivos y comunidades. ¿Hasta qué punto la inclusión de la comunidad en el capitalismo ha afectado sus procesos sociotécnicos, y entre otros asuntos, qué tanto se diferencian o se asemejan, con los efectos históricos causados por la Conquista española? ¿son éstas estrategias de irrupción y manipulación?

Es preciso enfatizar que el planteamiento de estas preguntas no desvaloriza el trabajo de apoyo de Instituciones como Artesanías de Colombia en las comunidades artesanas, por el 
contrario se necesitan. Sin embargo, cabe destacar que este trabajo, más allá de categorizarlo como un proceso de acompañamiento o apoyo por parte de distintos profesionales a las comunidades, se debe contemplar como un proceso cuyas partes (artesanos/profesionales) se relacionan de manera simbiótica para la definición y consecución de visiones de largo plazo que favorezcan al campo en el que están incrustados. Dicho de otra manera, la concepción del desarrollo del proceso se debe contemplar considerando a los artesanos como pares iguales frente a los profesionales, ya que de ellos se desprenden todos los aportes técnicos y tecnológicos de base para empezar a trabajar, y que deben ser potenciados por la contraparte (asesores, expertos, profesionales), para lograr los propósitos establecidos. Asi Barrera y Quiñones (2006) consideran que,

Es fundamental tener presente los elementos culturales y la tradición. Desarrollar nuevas alternativas de uso desde la tradición necesariamente implica conocer e interactuar a profundidad con la comunidad productora y con lo que es y ha sido su artesanía, no solo conocer las técnicas o las materias primas del lugar (Barrera y Quiñones, 2006:59).

El trabajo con comunidades artesanas es un proceso complejo que se debe tratar con cuidado. La tarea de evaluación a priori de cada estrategia y planificación propuesta debe encontrar un punto de equilibrio donde se convenga que los conocimientos técnicos y las tecnologías que confluyan entre artesanos indígenas y profesionales se sumerjan en un ambiente constructivo y no de prevalencia de uno sobre el otro. Los aportes técnicos, los elementos culturales y de tradición provenientes de una población son aspectos que se deben conocer, entender y valorar para ser cuidados. El mayor desafío es saber protegerlos y potenciarlos conforme al dinamismo de estos tiempos, que como parte de la sociedad, las comunidades artesanas no son ajenas a ello.

Atender a los parámetros del mercado implicó cambios de naturaleza socio-técnica en los modos de producción, interacción y relación de la comunidad Zenú. Así lo destaca Alcida Ramos (1992) en su trabajo "El indio hiperreal”, donde realiza una reflexión acerca de las transformaciones generadas en la última década en materia de escena indigenista (Ramos, 1992:3). Para la autora, no es viable pretender que un grupo indígena no se construya conforme a la naturaleza de estos tiempos enmarcados en un contexto globalizador. Ellos como cualquier otra porción de la sociedad, se encuentran inmersos en los flujos de vaivén. Por esta razón es que ellos logran adaptarse y condicionan sus productos a tales lineamientos. No obstante, es preciso considerar que las facultades autónomas en la toma de decisiones, la tecnificación y/o profesionalización de conocimientos que caracterizan a algunos indígenas posmodernos, son atributos que no se pueden evaluar en términos de autenticidad sino comprendidas en congruencia con los contextos de la presente época. Como medios de información para el conocimiento de la nuevas tendencias, Oittana (2013) afirma que:

Las nuevas tecnologías y los modernos medios de comunicación producen una mediatización cada vez más profunda de la realidad, de la naturaleza, de la vida. Mediatización de la imagen, del sonido, de la experiencia íntegra, lo que 
abre a una situación de producción indefinida de signos. Baudrillard constata que la publicidad, la moda y los mass media constituyen el centro de irradiación de los signos (Oittana, 2013: 258).

En efecto, los artesanos zenúes recurren a las vías de comunicación, como la televisión, revistas y el internet, para informarse de las últimas tendencias e inspirarse de los modelos que ven en estos medios y replicarlos en sus diseños. Si bien las comunidades artesanas están integradas por personas, en su mayoría de bajos recursos, esto no impide que los medios masivos de comunicación y vías tecnológicas como internet lleguen a ellos, mayormente por que la distribución de estos servicios se ha vuelto más incluyente, y porque, la comunidad Zenú lucha por el ingreso al mercado artesanal y por permanecer en él, siendo que han condicionado los parámetros proyectuales y productivos de sus productos, llegando hasta el sombrero vueltiao; esto ha ocurrido también como parte de la seducción que la infinidad de imágenes presentes en la red y en los medios de comunicación y por la creencia masiva instalada a partir del ingreso y reproducción de los circuitos de moda. Esta situación, también permite iniciar algunas preguntas, con relación a lo que Oittana (2013) define basado en Baudrillard:

La importancia que la comunicación y la información han adquirido en nuestras sociedades ocasiona la conformación de un tipo de sociedad en la cual el flujo de signos disuelve toda linealidad, toda trascendencia. Baudrillard cree que esta pérdida de la trascendencia se evidencia en la disolución de la instancia referencial -valores, finalidades, significados (Oittana, 2013:259).

Barrera y Quiñones (2006) sostienen que la dinámica industrial ha sumergido a los artesanos en distintas situaciones que para ellos pueden ser desconocidas, a tal punto que algunas de sus propuestas difieren con las demandas que establece el mercado. Esto es, por supuesto, resultado de un desconocimiento acerca de quién quiere artesanías, cómo las consume, dónde las compra, por qué las adquieren; respuestas que, según las autoras, son determinantes de diseño. Citando a Hernán Lozano, quien participó en el Primer Seminario de diseño artesanal en Colombia, las autoras valoran que el diseño es:

Como un mecanismo de comunicación, de trabajo en equipo, en donde el conocedor de las nuevas determinantes de diseño, el diseñador de nuestra sociedad industrial y sólo él, las pueda comunicar al artesano, quien las pueda interpretar y conjugar con sus propias determinantes, para desarrollar el producto que quiere esa sociedad (Lozano en Barrera y Quiñones, 2006:36).

Tal comunicación o traducción que puede realizar un diseñador se materializa en la orientación a nivel de composición de estos productos artesanales. En consecuencia, existen algunos ejemplos de piezas artesanales, que en virtud de responder a los lineamientos del mercado, terminan por disolverse, perdiendo la trascendencia y significación construida a lo largo de los años. En este sentido, se hace necesario el apoyo del diseñador, ya que los artesanos se enfrentan con realidades complejas, como las derivadas de los escenarios del 
mercado local y global. Según las autoras, el diseñador debe comportarse como un puente comunicativo o de traducción entre el consumidor y el artesano (Barrera y Quiñones, 2006:37). Hoy en día el trabajo de las Instituciones que velan por el desarrollo artesanal en Colombia, se dedican a infundir en las comunidades artesanas el valor que tiene su técnica originaria presente en cualquiera de sus productos.

En definitiva, el acompañamiento de Artesanías de Colombia desde los años 70 a la etnia Zenú se ve reflejado en las modificaciones implementadas en el sombrero vueltiao, que han implicado distintas etapas, y presencia de estándares que se hacen visibles en el objeto como parte de estrategias comerciales. Es el caso de la incorporación del color negro en contraste al color natural de la fibra; luego, las "pintas" que le otorgan más carga y fuerza cultural a la pieza; más tarde, la eliminación de "las pegas" (Ver Figura 5) que evidenciaban el término de una trenza y el comienzo de la otra. Y por último, se ha perfeccionado la técnica de trenzado para la fabricación de los sombreros finos vueltiao (aquellos de 29 y 31 vueltas), que además de ser motivo de orgullo para su artesano por las habilidades requeridas para hacerlo, se convierte en un objeto de más calidad y mayor precio frente a los demás.

Esta distinción antes y ahora enmarca al sombrero vueltiao dentro del segundo grupo de connotaciones que Barthes (1993) denomina como connotaciones tecnológicas. En este grupo, el objeto se define como un elemento de consumo, por lo tanto debe ser fabricado bajo ciertas normativas y estándares de producción y calidad. Toda artesanía es un objeto de consumo, una mercancía, que si bien son fabricados manualmente, también son sometidos a procesos de estandarización y normativas de calidad a lo largo de su proceso productivo. Como ejemplo de estos parámetros de calidad, se encuentra el mejoramiento de las uniones de las trenzas que conforman al sombrero vueltiao. Anteriormente, era indistinto tener en cuenta los acabados del sombrero ya que su importancia radicaba en su utilidad (tiempos modernos), y se restaba importancia a la unión de las trenzas con el mismo color en el que se terminaba, por lo tanto se notaban las "pegas". Sin embargo, luego de que esta pieza artesanal se perfiló hacia su inclusión dentro del mercado comercial en el que las exigencias de los productos son otras, estos detalles se fueron corrigiendo de manera que todo el sombrero se elabora partiendo de una misma trenza haciendo imperceptibles sus uniones (Ver Figura 6).

El sombrero creado sin uniones ha sido un cambio muy representativo para los zenúes, ya que evidencia el perfeccionamiento de su misma técnica. En entrevista, la artesana Luz Mila Suárez narra cómo este cambio en el sombrero se dio de manos de su padre.

El sombrero ha tenido una evolución, lo que el sombrero anteriormente era ya no lo es. [...] Los ajustes han sido por ejemplo en que el sombrero se hacía anteriormente con un pegue que era para la parte de atrás y para la parte de adelante, pero los clientes decidieron que no se pegara más. [...] Entonces mi papá que tomaba las decisiones, decidió que al sombrero tenían que quitarle el pegue [...] y mire lo que ha quedado. Dijo, ¿de qué van a vivir los artesanos? voy a reestructurarlo (L. Suárez, extraído de una comunicación personal, 8 de agosto de 2016). 
Esta innovación para su artesanía insignia se debe a que su atención estaba centrada en sus clientes. Además, es un cambio que se generó a partir de las distintas acciones que vino implementando Artesanías de Colombia en su región. Para 1998, año en que se estructuró el Manual de Diseño basado en la experiencia adquirida desde 1993 con el Laboratorio Colombiano de Diseño para la Artesanía y la Pequeña Empresa, se determinó el modo de intervención y de asesoría que se debía desarrollar, en dónde se hacía foco en la evaluación de los productos elaborados tradicionalmente en cuanto a su diseño, calidad y comercialización (Barrera y Quiñones, 2006:57). Esta política instaurada desde la década del 90 hasta estos tiempos ha perfilado la producción artesanal indígena hacia las exigencias del mercado, sin embargo, es preciso preguntarse si esta visión de posicionar las artesanías colombianas en el mercado local e internacional con la intención de adaptarlas a sus exigencias fue la mejor para todas las comunidades artesanas del país.

Particularmente en la etnia Zenú, los artesanos se aferraron a sus saberes ancestrales en el manejo de la caña flecha para poder subsistir. Es así como cada mejora efectuada sobre sus productos se fundamentan en condicionantes comerciales o de mercado, pero también se debe, en gran parte a la constante evolución que tienen estos objetos en las manos de largas generaciones de artesanos, como lo expresa Ricard, "En todo lo que va elaborando late un sordo proceso creativo, discreto, sin pretensiones, pero en marcha hacia la perfección. Cada reedición de lo mismo, aporta esas discretas mejoras que sólo la praxis y el uso enseñan" (Ricard en Calvera, 2004: 90).

\section{Fomento de la potencialidad económica de la artesanía}

En Colombia, las estrategias descentralizadas para potenciar las capacidades locales y regionales de cada grupo étnico artesano del país fueron motivadas por una serie de orientaciones propuestas por entidades internacionales con el objetivo de lograr una mejor participación de las artesanías en el mercado, por ejemplo: en 1997 la Organización Mundial de Comercio (en adelante, OMC), propuso un conjunto de directrices para que los productos artesanales tengan una mejor participación en el mercado internacional. Tiempo después, en 2003, la Organización Internacional de Trabajo (en adelante, OIT), presentó diversas estrategias para fomentar el empleo rural no agrícola en países latinoamericanos. Y finalmente, la UNESCO en 2007, definió varias políticas culturales y promovió la realización de algunos proyectos enfocados hacia el desarrollo de la actividad artesanal, ya que según esta misma organización, el panorama artesanal es clave para el desarrollo económico de las naciones, ya que opera desde un marco local y con elementos particulares que pueden llegar a interesar a mercados distintos (Fries, 2016:1-2). Estas gestiones, como parte de procesos globalizadores, incidieron en el corte diferenciador entre lo moderno y lo posmoderno, afianzando así, junto con los medios, la circulación y el consumo, lo que según Bauman (2002) viene implicando el pasaje entre dos sociedades distintas: una sociedad de producción (moderna) hacia una sociedad de consumo (modernidad líquida o posmoderna). En la primera se resolvían básicamente necesidades reales, es decir los productos valían por su valor de uso y durabilidad, en cambio en la segunda, la circulación 
y el consumo de productos están basados por necesidades creadas, por deseos o anhelos, que se convierten en el motor de la producción posmoderna.

La "necesidad", considerada por los economistas del siglo XIX el epítome de la "solidez" -inflexible, permanentemente circunscripta y finita-, fue descartada y reemplazada por el deseo, que era mucho más "fluido" y expandible [...] Ahora el deseo le toca el turno de ser desechado. Ha dejado de ser útil: tras haber llevado la adicción del consumidor a su estado actual, ya no puede imponer el paso. Se necesita un estimulante más poderoso y sobre todo más versátil para mantener la demanda del consumidor en el mismo nivel de la oferta. El "anhelo" es ese reemplazo indispensable: completa la liberación del "principio del placer” (Bauman, 2002:81).

En la sociedad actual, los medios de comunicación, la publicidad y los circuitos de moda incitan, junto con la industria, al consumo, basados en la adopción de distintos estilos de vida. Las comunidades originarias, los artesanos y las artesanías quedan así ciertamente huérfanas de espacio comercial y quedan desplazadas por el sistema propuesto por el hiperconsumo.

Hoy, lo que da ganancias es la desenfrenada velocidad de circulación, reciclado, envejecimiento, descarte y reemplazo -no la durabilidad ni la duradera confiabilidad del producto-. En una notable inversión de la tradición de más de un milenio, los encumbrados y poderosos de hoy son quienes rechazan y evitan lo durable y celebran lo efímero, mientras los que ocupan el lugar más bajo -contra todo lo esperable- luchan desesperadamente para lograr que sus frágiles, vulnerables y efímeras posesiones duren más y les brinden servicios duraderos (Bauman, 2002:19).

Baudrillard sostiene que el cambio de un modelo a otro fue generado por el avance y la perfección de las técnicas de comunicación y percepción ocasionando alteraciones sociales y culturales (Baudrillard en Oittana, 2013:255). Para Roca (2011), estos cambios han sido relevantes en lo social, en lo cultural, en lo productivo, y en todos los ámbitos de la sociedad, porque la tecnología digital, posee características disruptivas respecto de las ya conocidas y que han marcado los distintos ciclos evolutivos de la historia. En este sentido "el hecho digital es la tecnología disruptiva en el sistema productivo. Después de esto, la manera de ser competitivo y ser eficaz no va a ser la misma" (Roca, 2011). Para el autor, cada vez que una tecnología modifica el sistema productivo, está provocando consecuencias relevantes sobre los modelos sociales donde los procesos deben ser rediseñados y profundamente transformados, y el caso de la tecnología digital, no solo ha modificado el sistema productivo, sino también el sistema de distribución, publicación y de negocio (Roca, 2011). Trasladando esta afirmación al contexto artesanal Zenú, la analogía se sostiene desde la migración hacia otro sistema productivo producto de la manipulación de intervenciones de actores e instituciones externas a la comunidad, y que representan un cambio disruptivo para los artesanos ya que debieron modificar su circuito para adap- 


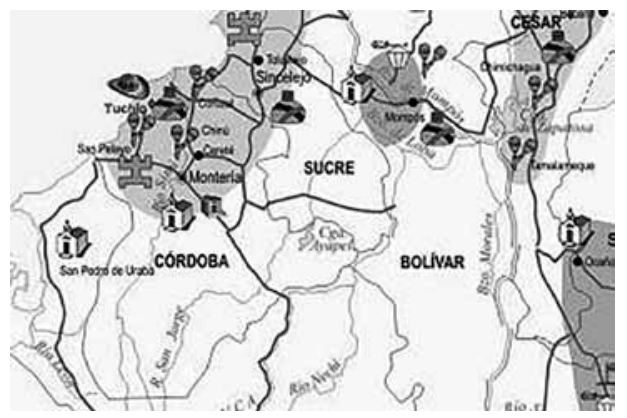

Figura 1.

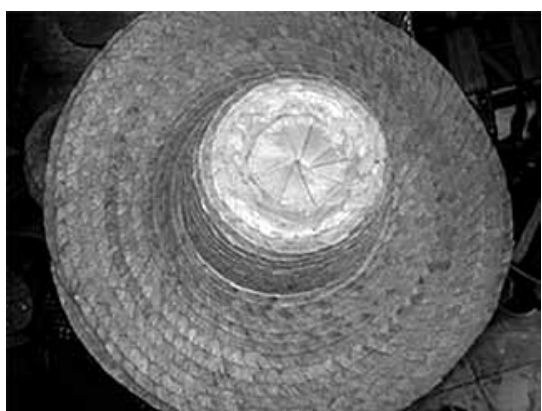

Figura 2.

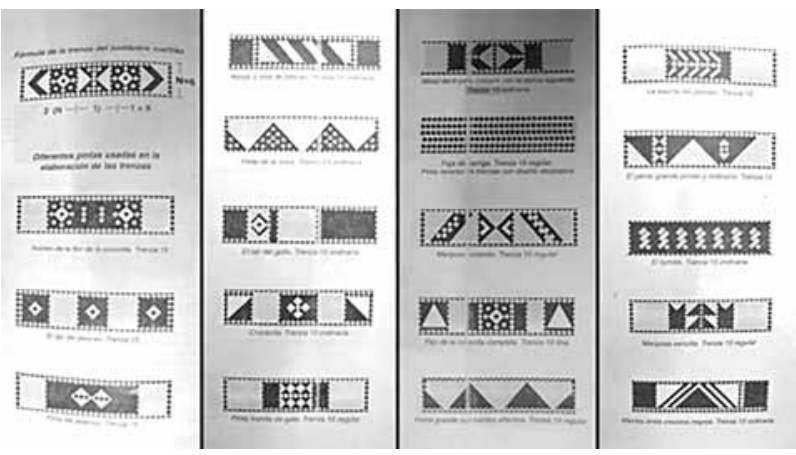

Figura 3.

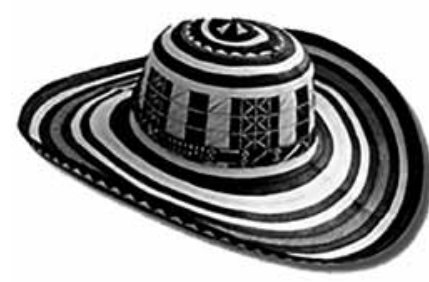

Figura 4.

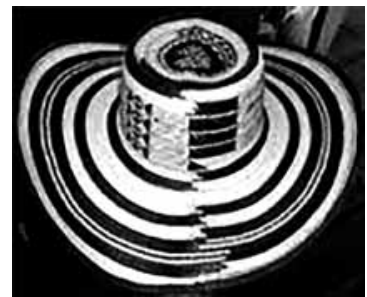

Figura 5.

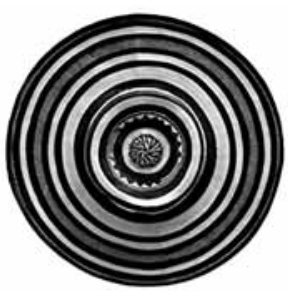

Figura 6.

Figura 1. Territorio indígena Zenú (Tomado de http://famituchincordoba.blogspot.com.ar/). Figura 2. Sombrero Vueltiao monocolor (Tomado de https://lasombrereria.wordpress.com/tag/sombrero-vueltiao/). Figura 3. Algunas "pintas del sombrero vueltiao" (Tomado de http://artesaniasdecolombia.com.co/Portal AC/Movil/Publicacion.jsf?contenidoId=4149). Figura 4. Sombrero Vueltiao. Símbolo cultural de Colombia (Tomado de http://www.escritoresyperiodistas.com/NUMERO52/images/vueltiaocolombia_000.jpg). Figura 5. Sombrero Vueltiao con "pegas". Figura 6 . Sombrero Vueltiao sin "pegas” (Tomado de https:// pablobuitrago365.files.wordpress.com/2011/11/dsc_0816.jpg). 
tarse al mundo capitalista. Ejemplo de ello son las modificaciones que se le han realizado al sombrero vueltiao, como la ampliación de la gama de colores que originalmente era de colores tierra a partir de los colorantes naturales. De este modo a través del uso de productos químicos y colorantes artificiales para desteñir y teñir de diferentes colores la fibra vegetal, la gama de colores naturales fue desplazada y considerablemente ampliada hacia una variedad de colores vivos, como el rojo, azul, amarillo, violeta, etc. hasta colores fluorescentes como el neón.

En las últimas décadas, la actividad artesanal ha ganado relevancia debido a que se ha fomentado la potencialidad económica de las artesanías. Es decir, bienes y saberes ligados a la identidad cultural de un grupo étnico son considerados como recursos para el desarrollo local. En consecuencia, la producción de objetos artesanales se concibe bajo fines turísticos comerciales, donde "la estrategia consiste en dinamizar procesos de desarrollo endógeno a partir de los atributos culturales que otorgan una identidad definida y particular a un grupo" (Benedetti, 2014:18). De manera complementaria, Jaramillo (2007) exalta la progresiva ampliación de los criterios culturales y económicos alrededor de las artesanías, en la medida en que esta actividad ha permitido concebir un modelo productivo dentro de una cadena de consumo.

Estas concepciones parecen estar sujetas a las nociones de la industria cultural, que según Adorno (1988), los objetos en tanto productos generados por la producción en masa, son percibidos por su valor comercial (mercancías, intercambio) que por su característica o valor distintivo.

Con el uso de técnicas de reproducción en serie estos bienes sufren una modificación para adecuarlos al consumo masivo, la marca más notoria es la estandarización. El poder de la industria cultural es tal que ya no necesita del valor social del arte para atribuírselo a sus productos, se los presenta directamente como una mercancía que promete diversión (Bertucci, 2013:4).

Las artesanías se han abierto al mercado, convirtiéndose en elementos de representación y adquiriendo un posicionamiento como marca de un país o una región determinada. Para el 2003, se establecen los Centros de Diseño de Artesanías de Colombia que se definen como:

Proyectos estratégicos que hacen parte del Proyecto Nacional Laboratorio Colombiano de Diseño para la Artesanía y la Pequeña Empresa, en que se busca integrar el sector productivo artesanal y la pequeña empresa a los procesos de desarrollo económico y social, mediante la introducción del componente de diseño para la innovación de productos, el perfeccionamiento de la calidad y la competitividad de los mismos, con el fin de adecuar la oferta de productos a la demanda del mercado nacional e internacional; hace énfasis en conocimientos científicos-tecnológicos, dirigidos al artesano y su actividad dentro de la proyección al nuevo siglo (Artesanías de Colombia en Barrera y Quiñones,2006: 58).

Es claro que el enfoque de este propósito se perfila hacia la adaptación de las artesanías a las demandas del mercado, lo inquietante es que en estas concepciones prevalece más 
las preocupaciones por la afinidad con el mercado que los valores de identidad, la carga cultural y tradicional inherente de este tipo de productos.

"Esto permite reflexionar en que esta propuesta no considera un diálogo de saberes entre el diseñador y el artesano, al contrario, se privilegian los conocimientos científicos tecnológicos sobre otras formas de conocimiento" (Barrera y Quiñones, 2006:58).

Si bien la dimensión cultural de un pueblo es considerada como aspecto fundamental para el desarrollo local, las nociones de identidad cultural y patrimonio, en muchas ocasiones, son relegadas por dimensiones mercantiles o de comercialización, siendo que sus elementos distintivos o de diferenciación se perfilen hacia una estrategia económica. Calvera lo expresa de esta forma,

La dinámica social y económica por el simple hecho de que se ocupa de la configuración estética de las mercancías, sea éstas materiales o digitales, y, así, su modo de ser es visto como el vehículo para esa estrategia económica y de marketing que encuentra en el modo estético de aparecer su principal argumento de venta (Calvera, 2004:24).

Rotman (2007) sostiene que el contacto directo de los artesanos con el turismo les ha facilitado conocer las tendencias y apreciaciones del momento (moda). Esto a su vez ha actuado "como catalizador de los cambios, generando una permeabilidad elevada a las exigencias del mercado; a partir del que se iría produciendo un ajuste, un acomodamiento de las artesanías a las aficiones, los deseos, y los requerimientos de los turistas" (Rotman, 2007:60). Los zenúes no han sido ajenos a los flujos mercantiles ni a las instancias que han favorecido la interlocución entre pueblos vecinos. De hecho, la confluencia de turistas, clientes, comerciantes, encuentros nacionales y regionales, bajo la figura de ferias o exposiciones, son cada vez más recurrentes. Son en estos espacios donde se abren las vías de intercambio de comunicación, de ideas, de información entre sus asistentes.

En primer lugar, son pueblos vecinos que tienen mucha interlocución. Existen muchos encuentros en términos comerciales, donde confluyen mucho estos pueblos indígenas, por ejemplo, en Expoartesanías en Bogotá, en la feria de las flores en Medellín, se hacen unos encuentros interdepartamentales también por Córdoba, regionales también. Yo tuve la oportunidad de asistir a unos eventos en Cartagena, en Barranquilla. En fin hay muchos encuentros regionales donde se concentran diferentes culturas y además por naturalidad, el indígena por costumbre esta dado al trueque. Yo te doy este sombrero, tú me regalas esa mola, y allí es donde se va compaginando el tema de cambiar artículos, intercambiar conocimiento, técnicas. Yo tuve la experiencia de que le di un sombrero a un amigo de la Guajira, y él me dio una mochila (I. García, extraído de una comunicación personal, el 04 de junio de 2016).

Para García Canclini (1995), existen marcadas diferencias étnicas, regionales y nacionales entre los distintos países, pero que no se convierten en un obstáculo que impiden su articulación en estos tiempos de globalización. Para el autor "La heterogeneidad multi- 
temporal y multicultural no es un obstáculo a eliminar, sino un dato básico en cualquier programa de desarrollo e integración" (García Canclini, 1995: 150). Lo antedicho enaltece el papel positivo de las diversidades culturales, las técnicas de producción y los hábitos de consumo como alternativa de desarrollo. Sin embargo, aún persisten las estrategias donde se prevalecen los planteamientos mercantilistas de inclusión de las artesanías al capitalismo por encima de los elementos culturales y de identidad de determinada región. Es necesario orientar estas estrategias en mecanismos que estructuren una propuesta con identidad cultural que interese al mercado, y no viceversa. Trabajando desde un contexto artesanal con miras a un sistema de consumo se puede salvaguardar algunos aspectos de su propio sistema sociotécnico.

\section{Los riesgos del hiperconsumo}

Se han expuesto de manera descriptiva las variantes y ajustes que han transformado al sombrero vueltiao desde su concepción original realizada por manos artesanas de la comunidad Zenú hasta lo que hoy es una mercancía que se ha modificado obligada por los parámetros del consumo en relación con los objetivos de la industria cultural de Colombia. Estas transformaciones hasta ahora descriptas no se han desvinculado del condicionante manual o hecho a mano al que se le ha incorporado mejoras relacionadas con el diseño, que han pulido las técnicas productivas de la artesanía. Sin embargo, en este apartado se expondrán dos casos, uno a nivel de mercado local y otra a nivel de mercado global, que condujeron la producción artesanal Zenú a instancias semi-industriales e industriales, respectivamente; atentando directamente sobre la supervivencia y calidad de vida de los artesanos, sin olvidar las implicancias que repercuten en la identidad de toda una región. Dentro del mercado local, el caso que excede los límites de hecho a mano de la producción Zenú, fue el creado por aquellos comerciantes con suficiente liquidez económica y que perduran hasta hoy, que han abierto talleres en ciudades centrales del país, como Medellín y Bogotá, y que cuentan con capacidad industrial en máquinas y herramientas, como para fabricar seriadamente productos similares a los elaborados de manera artesanal. Estos talleres suelen fabricar gran cantidad de productos de una misma referencia, por lo tanto, necesitan de mucha materia prima para cubrir sus objetivos de producción. En este caso la principal materia prima que necesitan es la trenza de caña flecha que la compran por metro a los artesanos trenzadores de Tuchín. Esta modalidad es muy conveniente para aquellos artesanos que se dedican sólo a trenzar, ya que tienen disponible un comprador fijo y seguro; pero afecta a aquellos artesanos que también necesitan metros de trenza para elaborar sus artesanías, ya que en muchas ocasiones, no han podido conseguirla o escasea debido a que ya las han vendido en su totalidad a los comerciantes. Esta situación fomentó un circuito desleal que ha dejado en total desventaja al artesano que trabaja en su territorio ancestral con una producción de menor escala, ya que su espacio de trabajo se limita a la infraestructura de su hogar y como máximo a una o dos máquinas de coser en general muy antiguas. En consecuencia, esta desigualdad productiva entre grandes comerciantes y pequeños artesanos ha llevado a que la mayor producción de productos en caña flecha se manufacturen fuera de su territorio ancestral. Para contrarrestar estas producciones se 
han tomado e implementado medidas como la rúbrica de producto artesanal añadiéndoles un sello de origen. Al respecto Lauer (1981) sostiene que:

Hasta hace no mucho tiempo la artesanía era artesanalmente producida. Pero de un tiempo a esta parte ha venido fortaleciéndose la tendencia a que las formas plásticas originalmente exclusivas de la producción artesanal sean reproducidas también en incipientes talleres industriales, ya no predominantemente por artesanos independientes, sino ahora por trabajadores asalariados (Lauer, 1981: 12).

Lamentablemente estos talleres aún persisten porque la propuesta de trabajar en una ciudad con sueldo fijo resulta tentadora sobre todo para los jóvenes artesanos ya que lo ven como una oportunidad de progreso y estabilidad. Además, también es interesante la propuesta para aquellos artesanos trenzadores ya que de antemano saben que tienen un cliente fijo que les compra cierta cantidad de trenza mensual, por eso se hace muy difícil controlar la expansión de estos talleres ya que hay artesanos que, aunque sean pocos, se benefician de ellos.

La segunda situación que transgredió los condicionantes manuales de la producción artesanal, es el caso de la importación de sombreros vueltiao provenientes de China. Aprovechando la oportunidad de que no todos pueden tener un sombrero original tejido por los propios indígenas de la comunidad artesana Zenú, y las ideas vinculadas con la maximización del consumo, los chinos lograron producir una gran cantidad de sombreros, reemplazando la caña flecha con una fibra plástica, una simulación que viene a copiar o falsificar lo real (Baudrillard, 1978). Con la fórmula matemática, descifrada por Puche Villadiego (Ver Figura 7), se ha podido identificar el número de pies de las trenzas elaboradas de caña flecha, y así determinar si el sombrero vueltiao es de 15, 18, 21,24 o 29 vueltas, según la fórmula matemática que sigue:

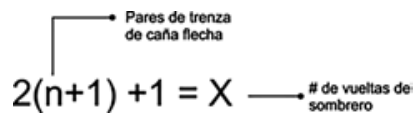

Figura 7. Fórmula del sombrero vueltiao según Puche Villadiego.

En visita al resguardo indígena de San Andrés de Sotavento empresarios chinos se llevaron varias muestras del sombrero, quiénes luego de dos años, y con la ayuda de la tecnología industrial empezaron a fabricar miles de sombreros similares a los vueltiao a menor costo: "El señuelo de la representación fiel de la realidad ha tentado al arte occidental desde el Renacimiento, sobre todo en la producción mediocre destinada al consumo masivo" (Arnheim en Levis, 2011:30). Para Levis (2011), la imagen es el resultado de un simulacro digital producto de una modelación de raíz matemática (Levis, 2011:24), en este caso no es una imagen sino un objeto resultante bajo las mismas condiciones: una fórmula mate- 
mática, una tecnología, un simulacro que reproduce la realidad pero la va vaciando de sus significaciones. Según fuentes de la DIAN ${ }^{8}$, entre el período de enero y octubre de 2012 fueron importados 944.081 unidades de estos sombreros por un valor de US $\$ 525.837$ con impuestos y seguros incluidos: "lo real no es ya sólo objeto de representación, ahora también es objeto de reproducción indefinida, infinita. La realidad se disipa, se volatiliza por exceso" (Baudrillard en Oittana, 2013: 257).

Con el apoyo de los medios de comunicación nacional, el cacique del resguardo en compañía de algunos artesanos realizó la denuncia que permitió frenar la importación de estos sombreros al país. Gracias a ello, la Superintendencia de Industria y Comercio decretó bajo la Resolución 439 del 17 de enero de 2013 una

Medida preventiva y de suspensión inmediata sobre la producción, comercialización o venta de todo sombrero que imite, aparente ser o representar, se asemeje o evoque al sombrero que identifica la denominación de origen protegida (Tejeduría Zenú) y que es también identificado como sombrero vueltiao.

Luego, y según el Comunicado de Prensa No 18, expedido por la DIAN en febrero de 2013, se logró incautar un total de 69.800 unidades de los sombreros chinos.

\section{Las condiciones de la etnia Zenú, el sombrero vueltiao y su conexión con los problemas complejos (wicked problems)}

Se ha intentado describir un recorrido de las transformaciones que ha sufrido el sombrero vueltiao según los cambios del contexto, dinámico y cambiante, que ha influenciado la gestación de modificaciones, en un camino hacia una evolución de técnicas de la artesanía. En este punto, desde las vertientes de la industria cultural, el diseño ha jugado un papel importante, ya que la competitividad no depende solo de ofrecer un buen producto al mercado, sino también de saber implementar de manera coherente las fases de su cadena de valor. En efecto, los procesos de la artesanía y el diseño desarrollados desde 1997, año en que comenzó el primer Laboratorio de Diseño en Colombia hasta la fecha, han generado toda una fundamentación conceptual y metodológica dirigida a la incorporación del diseño en la producción artesanal. En principio, el objetivo se centró en impulsar el desarrollo del sector artesanal colombiano, por eso se planteaba como principal estrategia vincular el diseño en la producción de artesanías para generar productos competitivos, proceso en el que esta disciplina desempeña un rol fundamental (Santos, 2011). A través de la creación de un Centro de Diseño e Investigación Artesanal,

Los diseñadores buscarían su inspiración en motivos autóctonos propios que serían presentados según los gustos y preferencias de la época. Por otra parte, estos diseñadores serían quienes escogerían y mejorarían, si fuera el caso, las buenas y originales ideas que los artesanos fueran presentando en concurso de diseño (Barrera y Quiñones, 2006:24). 
Estas acciones corresponden a procesos de diseños tradicionales con modelos lineales de causa y efecto, que ignoran circunstancias sociales, económicas y ambientales que otorgan un grado de complejidad mayor a las propuestas en estos laboratorios. El común denominador de estas poblaciones indígenas es su vulnerabilidad frente a problemas de mayor envergadura, con características cambiantes, contradictorias y reticentes que requieren de un trabajo interdisciplinar donde prime la cohesión de los intereses de las diversas áreas involucradas: "Debido a las interdependencias complejas del problema, cualquier esfuerzo para resolver un aspecto de un problema intrincado usualmente revela o crea otros, [...] e involucran a muchas partes interesadas con agendas, preocupaciones y conjuntos de valores opuestos (Irwin, 2017:4).

Mouchrek y Krucken (2018), sostienen que los problemas de estos tiempos son generalmente complejos, en especial los de ámbito social, que como características principales, suelen ser incompletos, contradictorios y de naturaleza cambiante. Ante tales cualidades, los métodos para su solución deben ser diferentes a los implementados para tratar temas comunes, y además requiere de actores capaces de gestionarlos (Mouchrek y Krucken, 2017). En este punto, las autoras reflexionan acerca del potencial que tiene el Diseño en el manejo de las problemáticas de esta tipología, cuyas conclusiones afirman que en definitiva el foco de acción se ha expandido hacia el abordaje de aspectos concernientes a problemas sociales y de estructuras organizacionales, promoviendo a que "el enfoque del Diseño está evolucionando hacia una perspectiva sistémica, aumentando su campo de acción" (Mouchrek y Krucken, 2017:125). El rol de un diseñador en esta demanda de problemas intrincados resulta prometedora gracias a un perfil profesional que articula distintas habilidades con metodologías que otorgan cierta practicidad a la hora del análisis e implementación de posibles soluciones. Tales "virtudes" se encauzan en capacidades relacionadas "con adquirir una visión sistémica, desenvolverse en entornos multidisciplinarios, sintetizar y producir contenidos coherentes en combinación con metodologías centradas en el usuario y creación de prototipos que los inclina hacia la acción y los conduce a la proactividad" (Mouchrek y Krucken, 2018: 127-128).

Para la resolución de problemáticas que aquejan a los pueblos originarios es de vital importancia entender de fondo sus prácticas, sus costumbres, sus técnicas ancestrales, sus modos de producción, etc. e ir ampliando el foco de atención desde los modos de hacer particulares de determinada comunidad hacia la identificación, no solo de los problemas, sino de los actores e instituciones involucrados para entablar estrategias con "un enfoque transectorial/transdisciplinario, de colaboración, cooperación y compromiso" (Irwin, 2017:4). Estas perspectivas de transdisciplinariedad y colaboración enmarcan la labor del diseño en un enfoque más profundo: el social. La tarea de estimular de mejor manera la proyección individual de cada artesano no es sencilla; requiere de la conformación de un equipo de capacitación interdisciplinar compuesto, además de diseñadores y asesores en arte, por sociólogos o profesionales en trabajo social que sirvan de puente comunicativo entre las partes diseñador/artesano. En general, los pueblos indígenas suelen ser de costumbres muy arraigadas, que para entablar un acercamiento con ellos y generar algunos cambios que modifiquen sus costumbres, pueden dificultar el desarrollo de cada uno de los programas. Según un estudio realizado por Ángel de Chavarri en 1971, capacitar a la población artesanal en un Centro de Diseño e Investigación Artesanal, 
Generó una ruptura en relación con las formas de pensar y hacer en el taller artesanal tradicional, en donde el artesano integralmente, de acuerdo con una estructura socio cultural, es quien concibe sus creaciones, las produce, las comercializa y, en muchas ocasiones, usa como parte de su economía de autosubsistencia (Barrera y Quiñones, 2006:24).

Esta propuesta de sacar al artesano de su casa taller, significó y sigue significando una ruptura de sus costumbres más arraigadas construidas en el tiempo. Sin embargo, en esta instancia radica la importancia de un equipo de trabajo interdisciplinar, donde personas expertas en el manejo de comunidades étnicas sean quiénes les transmitan cada uno de los programas de capacitación y las ventajas que le puede traer en el desarrollo de sus artesanías. No obstante, por falta de recursos económicos destinados a estos trabajos con artesanos, en la mayoría de los casos, no existen estos puentes que faciliten al diseñador el manejo de sus pares indígenas, por lo tanto él mismo debe de desempeñar una labor, además de facilitador, debe ser un motivador de procesos (Montaña en Guzmán y García, 2010). Para el diseñador industrial Diego Granados, desde su experiencia en el trabajo con artesanos, argumenta en entrevista, sobre la importancia de tener un puente entre ellos como diseñadores y los artesanos para hacer más fácil la comunicación:

Habían unas capacitaciones que lograban mucha asistencia ya que venían de la mano con un trabajo social, se hacían visitas a la comunidad, con frecuencia se buscaba solucionar los diferentes problemas que se pudieran presentar, eso ayudaba bastante a que hubiese un éxito en la participación de otros proyectos posteriores. No lograron el mismo nivel de asistencias precisamente a la falta de esta trabajadora social, ella era un puente. Las comunidades artesanas suelen tener muchos problemas internos y las trabajadoras sociales ayudan a dar como un nuevo sentido a las cosas (D. Granados, extraído de una comunicación personal, agosto 09 de 2016).

Van Dommelen (1972) enfatiza sobre la imperiosa necesidad de trabajar con el artesanado de manera integral. Como caso ejemplo, exponen las autoras Barrera y Quiñones (2006) el caso de Sandoná, Nariño en Colombia, donde la recomendación era estructurar un programa integral, que además de intervenir en desarrollos experimentales de diseño de artesanías, también interviniera en temas de carácter social como: protección infantil, nutrición, planificación familiar, entre otros. Sin duda, es una propuesta con un trasfondo social que se extiende y sobrepasa los límites netamente mercantiles o comerciales, incluidos los del diseño y la producción artesanal, que para ejecutarla se necesita reunir a un grupo de profesionales de distintas áreas. Es loable e innovadora esta recomendación realizada por Van Dommelen en 1972, porque eleva a un nivel mayor el campo de acción al nivel comunitario. Montaña (2010) por tanto afirma que el diseño también debería serlo, ya que las soluciones deberían ser pensadas y generadas en un espacio cooperativo, donde el diseñador oficie como "gestor y facilitador de procesos de creatividad dirigidos pero no direccionados por él dentro de talleres participativos" (Montaña en Guzmán y García, 2010:33). 
Dentro del campo artesanal Zenú existen muchas problemáticas de carácter social, ambiental y económico. Sin embargo no son problemáticas independientes, por el contrario, son circunstancias que están vinculadas o relacionadas en una red de problemas que fluctúan entre sí. En la medida que se van identificando, se van relacionando y organizando en una malla intrincada en la que el movimiento de uno afecta al otro, por eso el énfasis de vincular problemas de carácter social y ambiental para llegar a soluciones que atiendan a problemáticas de mayor escala (Irwin,2012:26). La red de conexiones de problemas de la producción artesanal Zenú afecta directamente a sus artesanos. Como problemática social, el $82 \%$ de los zenúes asentados en el municipio de Tuchín se encuentran inmersos en la pobreza (Ver Figura 8) y como principal fuente de sustento tienen al oficio artesanal (Ver Figura 9).

Asimismo, son pocas las hectáreas de cultivo de caña flecha que están destinadas a los indígenas. Como se explicaba en párrafos anteriores, en las regiones cordobesas la mayor parte de los terrenos corresponde a unos pocos hacendados, disminuyendo así las probabilidades de que un indígena trabaje la tierra y tenga otra fuente de sustento que le ayude a mejorar su calidad de vida. Por tal razón, al pertenecer estos terrenos a personas ajenas al campo artesanal, se dificulta la implementación de cultivos o plantación sostenible de la palma. De ella se deriva otro problema relacionado con el cambio climático, ya que incrementa los tiempos de verano generando sequías duraderas, que afectan tanto a la calidad de la fibra como al costo de venta de la palma. Todo este compilado de situaciones pone en desventaja al artesano con recursos limitados, generándole una competencia desigual frente a otros comerciantes que tienen un músculo financiero para adquirir la palma a altos costos. Por otra parte, se encuentra la devaluación en el precio venta del producto. La diferencia es abismal en los precios que compran los intermediarios a los artesanos, y el precio final de venta que se ofrece en los locales de las principales ciudades del país. Los intermediarios son personas ajenas a la etnia, que hacen las veces de puente entre el artesano y el comerciante. Ellos, como estrategia de negocio buscan conseguir el mejor precio del producto, para luego revenderlo al comerciante final y generar mayor rentabilidad. Buscar el precio más bajo perjudica a la economía del artesano, ya que con cada descuento que le otorgue a su intermediario está reduciendo su utilidad y con ello su rentabilidad.

Todo este panorama de conflictos y situaciones adversas que se encuentran en la producción artesanal Zenú, generan que los jóvenes muestren desinterés en desempeñar el oficio, ya que no ven rentabilidad ni mejoras en la calidad de vida de su familia, por eso prefieren ocuparse de trabajos informales para conseguir dinero más rápido. La competencia desigual que tienen los artesanos se torna más profunda al no tener las estrategias ni recursos para contrarrestarla, siendo que otro de sus problemas de índole social son los límites de acceso a estudios de carácter técnico o superior.

En la siguiente malla (Ver Figura 10) se condensan todas las problemáticas descritas, donde se intenta conectar de manera gráfica los distintos niveles (individual, regional, nacional) que abarca el análisis de la producción artesanal Zenú. El objetivo de enmarcar las problemáticas de la etnia Zenú y relacionarlas de manera gráfica en una red es porque permite entrever dentro de los problemas mayores todas aquellas variantes del problema ya que encuadra su marco de realidad, determinando dimensión, tiempo y lugar. Para Di Bella (2018), la elaboración del mapeo del wicked problem promete 
Enmarcar el tema de interés o caso problema de diseño, dentro de las líneas de los problemas mayores que pueden contenerlos y/o que pueden estar vinculados con los encuadres contextuales de índole sociotécnica, económica, política y ambiental. De este modo (permite) acceder al descubrimiento de las variables de un problema, la comprensión de su envergadura, las interdependencias, las posibles escalas y la discusión compartida sobre un mismo asunto (Di Bella, 2018:190).

Es así como en el marco de nivel global se sitúa al sistema hipercapitalista y en el nivel nacional se ubica el conflicto armado en Colombia como las principales causantes del desprendimiento de las demás problemáticas existentes. Por ejemplo, las gestiones del sistema hipercapitalista vigente en la actualidad, abre más la brecha entre las personas de mayor poder adquisitivo y las personas inmersas en la pobreza, es decir favorece el aumento de la inequidad social (Oxfam', Enero de 2015).

Actualmente, 80 personas poseen la misma riqueza que el 50\% más pobre de la población mundial; esto quiere decir que 3.500 millones de personas comparten la misma cantidad de riqueza que estas 80 personas enormemente ricas. Dado que la riqueza del resto de la población no se ha incrementado al mismo ritmo que la de las 80 personas más ricas, la participación de este grupo en la riqueza mundial ha aumentado, al igual que la brecha entre las personas muy ricas y el resto (Informe de Oxfam, Enero de 2015).

En un gráfico ilustrado en el informe de Oxfam, se muestra que en 2014 el 1\% de la población más rica poseía el $48 \%$ de la riqueza mundial, mientras que el $99 \%$ de la población restante debía compartir el 52\%. Al proyectar esta tendencia (líneas discontinuas), el informe indica que para el 2020 ese 1\% de la población rica superará el 54\% de la riqueza mundial (Ver Figura 11).

Tal situación se traduce en personas con poder y personas vulnerables, que para efectos de la etnia Zenú, son los indígenas quienes conforman el segundo grupo de personas, siendo que aprovechándose de su posición se apoderan de territorios que no les pertenecen a través de métodos violentos, causando terrorismo, miedo, despojo de tierras y desmovilizaciones.

De acuerdo con el análisis hecho por la Fiscalía 13 de Justicia y Paz, para llevar a cabo su plan de expansión, las ACCU (Autodefensas Campesinas de Córdoba $y$ Urabá) recurrieron al desplazamiento forzado de poblaciones enteras como arma de guerra, con el fin de tener el control estratégico del territorio. Estos éxodos masivos se daban luego que los paramilitares ejecutaban varios homicidios selectivos, cometían una o varias masacres, desaparecían personas, mayoritariamente padres cabeza de familia, hurtaban ganado o amenazaban directamente a los pobladores para que abandonara la región, o pena de perder la vida. Con las tierras abandonadas y la orden directa a los pobladores de no retornar a sus viviendas, los paramilitares comenzaron no solo a ejercer un 
férreo dominio territorial sino también a controlar las actividades sociales y económicas de las zonas dominadas (Verdad Abierta, 14 de febrero de 2014).

Las consecuencias derivan y se reflejan en circunstancias de desesperación para los artesanos quiénes sin tierras para trabajar deben buscar otras fuentes de sustento, y sin mayores probabilidades para ingresar a una educación técnica o superior, se aferran a su oficio ancestral para poder sobrevivir. Si bien las artesanías son elaboradas con recursos propios de la región, la materia prima para fabricarla también tiene un costo. Lamentablemente para los zenúes, conseguir la palma se ha convertido en una odisea, primero porque la mayoría de los terrenos de su región no pertenecen a ellos, y segundo porque los efectos del cambio climático, que como problemática global, prologan el período de verano y sequía que afectan directamente al crecimiento y desarrollo de los cultivos de caña flecha, haciéndola escasa y costosa. Desde su experiencia como artesano, Reinel Mendoza, manifiesta en entrevista, que ha disminuido la siembra de la palma caña flecha,

Actualmente tenemos un déficit que es en la parte de la fibra. La mata como tal la hemos venido bajando en la siembra, no le hemos puesto atención. De pronto el gobierno o el mismo resguardo indígena a lo que es la cultivación de la caña flecha requerimos de más materiales. Ante todo necesitamos tierras para sembrarla. Desde el año pasado hacia acá la producción de la fibra ha mermado, ha tenido un costo muy elevado (R. Mendoza, extraída de una comunicación personal, 04 de agosto de 2016).

En complemento, el artesano Isaac García sostiene que otro factor responsable que se suma al déficit de caña flecha es la prolongación del verano que afecta considerablemente el desarrollo de sus hojas,

Los momentos más críticos en donde se escasea la caña flecha, son los meses entre enero y abril, que a veces se extienden. Esos meses son los más críticos para los artesanos, porque al momento de no existir lluvia, las plantas dejan de producir hojas, y por ende se disminuye la producción, porque la fibra se extrae es de la hoja (I. García, extraído de una comunicación personal, 04 de junio de 2016).

Este compilado de situaciones/problemas evidencia el escenario vulnerable donde subyacen los zenúes. Con ellos coexisten varias complejidades que son congruentes dentro de los quince desafíos globales de la humanidad, como son: pobreza, población y recursos, desarrollo sostenible, cambio climático, educación y aprendizaje; y por último, falencias en cuestiones de salud (The Millenium Project, 2017). En definitiva, es un panorama difícil para esta comunidad, sin embargo el abordaje de estas problemáticas bajo un pensamiento lineal resulta ser inadecuado e ineficiente ya que se ignora la complejidad del problema dificultando su comprensión desde múltiples perspectivas provenientes de organizaciones y actores interesados que, con participación, compromiso y coordinación conceden un manejo efectivo de la problemática (Australian Public Service Comission, 2007:11). 


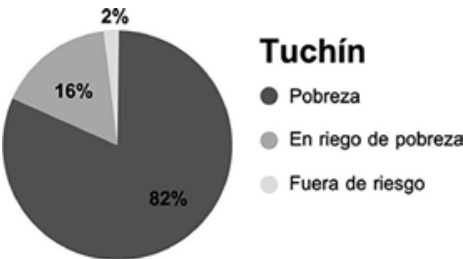

Figura 8.

\begin{tabular}{|l|l|}
\hline \multicolumn{2}{|l|}{$\begin{array}{l}\text { Artesanías como fuente principal de } \\
\text { ingresos del hogar. (Tuchín) }\end{array}$} \\
\hline Sí & $76 \%$ \\
\hline No & $24 \%$ \\
\hline Base & 49 \\
\hline
\end{tabular}

Figura 9.
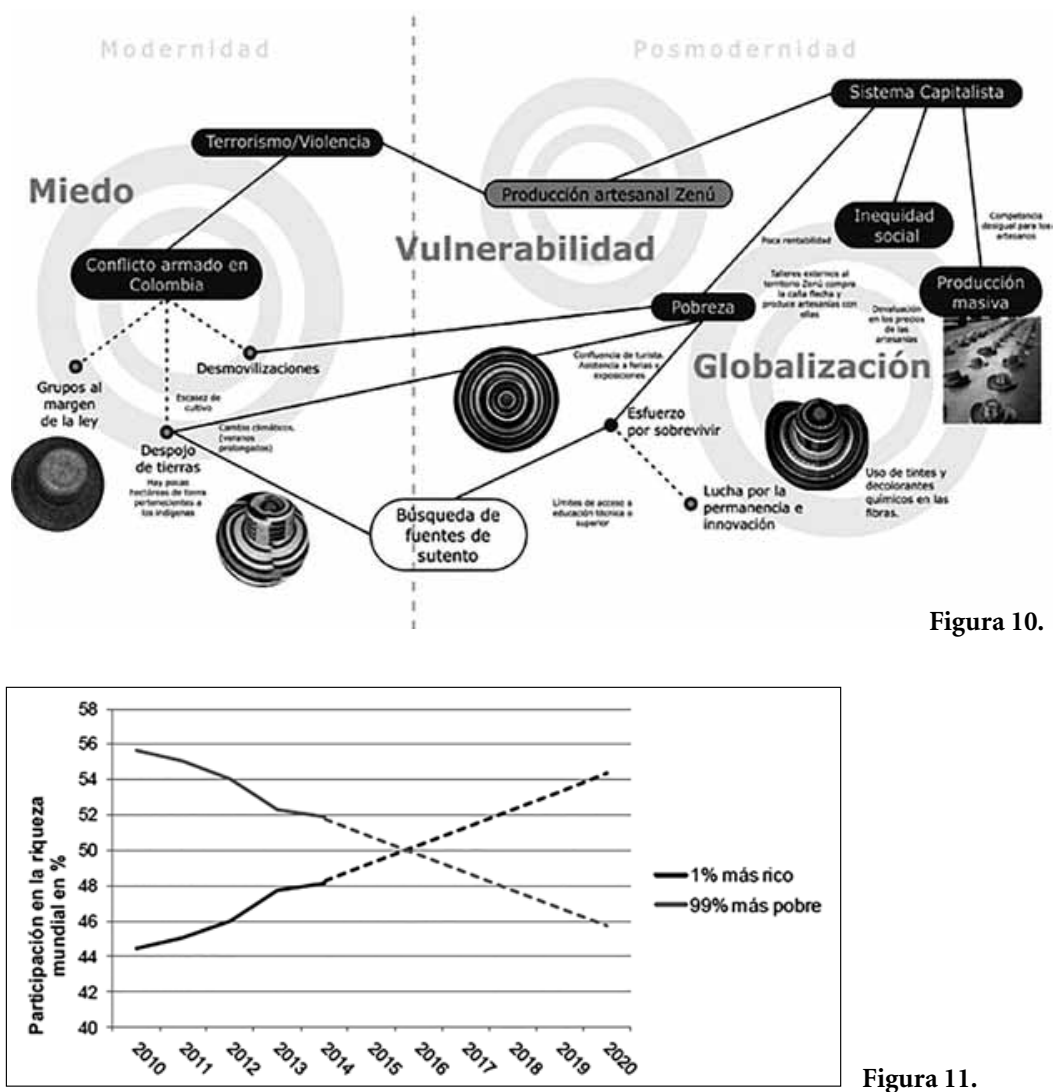

Figura 11.

Figura 8. Línea de Pobreza. Tomado de "Diagnóstico del sector artesanal y las particularidades regionales en Colombia, artesanías en barro de Chamba, filigrana y caña flecha”, por Rafael Monserrate; Daniel Serrano, 2016, p. 7. Figura 9. De "Diagnóstico del sector artesanal y las particularidades regionales en Colombia, artesanías en barro de Chamba, filigrana y caña flecha”, por Rafael Monserrate; Daniel Serrano, 2016, p. 6. Figura 10. Malla de wicked problem para producción artesanal Zenú (Elaboración propia). Figura 11. Participación en la riqueza mundial del 1\% más rico y del $99 \%$ más pobre de la población, respectivamente. Tomado de “Riqueza: tenerlo todo y querer más”, Informe realizado por Oxfam, 2015, p.3. 


\section{Acerca de los actores implicados}

Evidentemente no existe una única solución para estas problemáticas existentes relacionadas con la etnia y la producción artesanal Zenú. Se hace imperativa la intervención de distintas instituciones, sectores, disciplinas y profesionales que planteen múltiples acciones a corto, mediano y largo plazo que se direccionen a la consecución de un futuro sostenible. Es probable que dentro del abanico de soluciones se contemplen, por nombrar algunos, mecanismos institucionales y legislativos innovadores de amparo, resguardo y protección. A su vez, que se estudien y establezcan estrategias de gestión ambiental y manejo sostenible de los recursos utilizados, no sólo para la artesanía sino para las otras actividades laborales, que aunque se desempeñen en menor escala, también inciden en el manejo responsable de los recursos naturales. La resolución de la red de problemas intricados se logra desde los lazos interdisciplinares que se puedan forjar y desde la predisposición de sus actores en colaborar y trabajar en conjunto. No obstante, las relaciones entre los actores implicados también suelen ser "intricadas", ya que las partes involucradas tienen opiniones, creencias, costumbres y formaciones distintas que desembocan en desacuerdos y situaciones conflictivas. En efecto, cualquier reunión, conglomeración o foros de discusión que integre a un grupo de personas genera espacios de divergencia y de convergencia entre sus integrantes, sin embargo es esencial el manejo de estas relaciones entre las partes ya que garantiza la resolución de los problemas en discusión (Irwin, 2017:9).

Dentro de los stakeholders o actores implicados en el campo artesanal Zenú (Ver Figura 12), se encuentra el Ministerio de Industria y Comercio y el Ministerio de Turismo que subordina a Artesanias de Colombia. Asimismo, se encuentran otras Instituciones gubernamentales como el Ministerio de Agricultura y Desarrollo Rural, encargada entre otras cosas de la restitución de tierras, que trabaja en conjunto con la Alcaldía Municipal y el Gobierno Departamental de Córdoba. Por su parte se encuentran las Organizaciones No Gubernamentales (ONG) que apoyan, sin ánimo de lucro, a la comunidad en general y a las asociaciones de artesanos que estén organizadas. Por último, se encuentra la Institución del Servicio Nacional de Aprendizaje (SENA) que apoya la parte de los Programas de Formación Técnica y Complementaria en diferentes áreas. Cada una de estas instituciones y organizaciones mencionadas vinculan a personas de distinta formación, las que entran en interacción bajo esquemas de relaciones de confianza, simbióticas o mixtas (Irwin, 2017:9) cuyo tipo de relación entre una institución y otra se analizó en el esquema que sigue: 


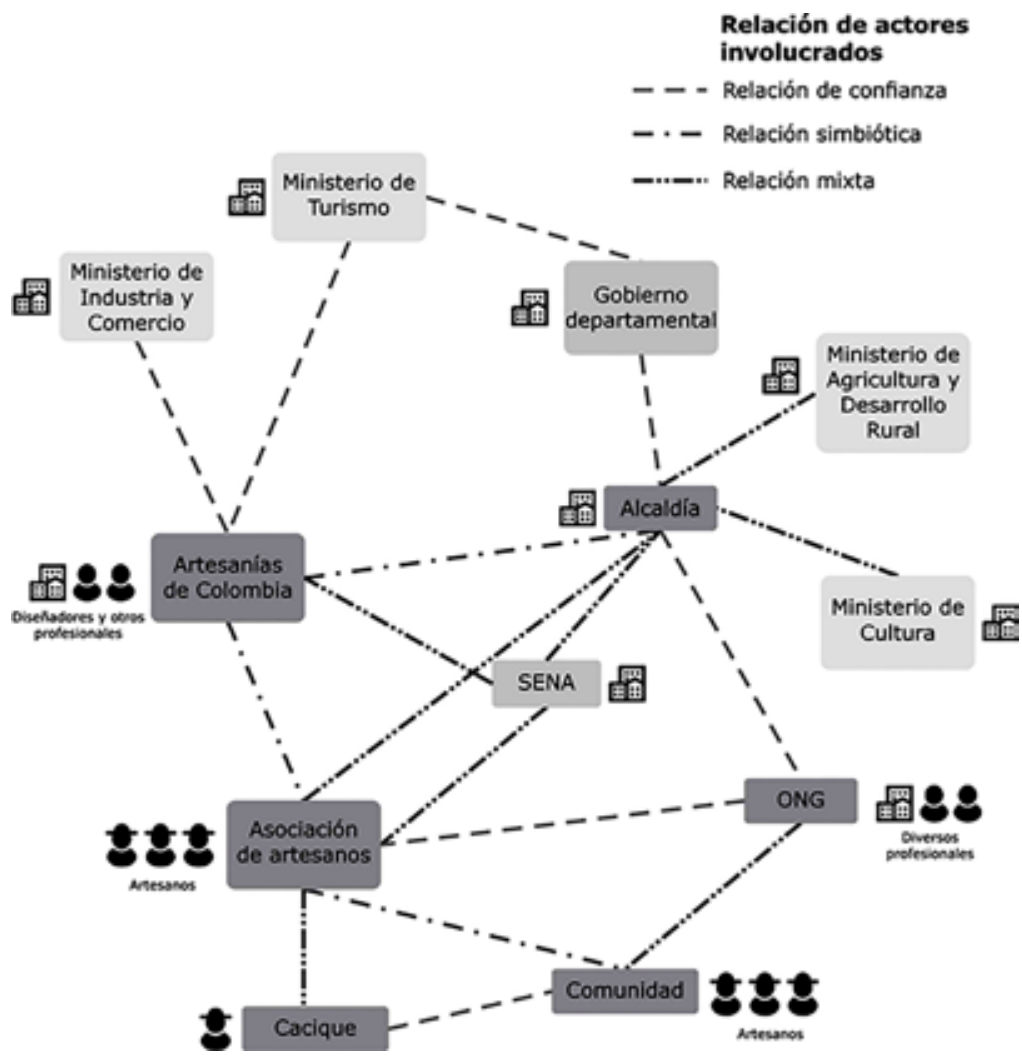

Figura 12. Relación de actores involucrados (Elaboración propia).

Artesanías de Colombia ha apoyado al sector artesanal colombiano desde hace más de 50 años, con esta experiencia ha entendido cómo es la dinámica y ha implantado estrategias para solventar las distintas problemáticas que se presenten en las comunidades. Particularmente en la etnia Zenú, como parte de su estrategia institucional, ha instaurado Laboratorios de Diseño donde artesanos y diseñadores confluyen para atender distintas situaciones a nivel proyectual y productivo de los productos. No obstante, en estos espacios no sólo se atienden proyectos sino que se gestionan recursos para resolver otras problemáticas. Por ejemplo, a través del Gobierno y Alcaldía Municipal, junto con la Asociación de Artesanos Zenú han gestionado recursos económicos para comprar algunas hectáreas de terrenos que los mismos indígenas puedan trabajarlas en cultivos de maíz, de tubérculos y de la 
palma caña flecha. Este proceso, a su vez fue acompañado por el SENA, entidad gubernamental, que los capacitó en temáticas agrícolas para un mejor manejo de la tierra y de los cultivos, cuidando el aspecto ambiental. Por otra parte, anualmente se organiza una malla de programas de capacitación de acuerdo a un análisis previo de la situación artesanal. Cada programa se realiza y se fundamenta en los criterios a mejorar y se dictan cursos gratuitos a lo largo del año. Dentro de sus temáticas están las herramientas de creación e innovación de productos, donde hay relación directa con diseñadores, pero también abordan temas de orden administrativo, financiero, donde asesoran y enseñan a los artesanos temas de rentabilidad, préstamos y utilidad para que vean en el oficio un negocio.

Desde esta perspectiva, las distintas problemáticas se han abordado, en colaboración con otras entidades especializadas en temas específicos, desde varios frentes de acción. El llamado de colaboración que ha realizado Artesanías de Colombia a otras organizaciones gubernamentales para acatar las problemáticas del sector artesanal colombiano es un proceso que aún es incipiente pero en el que se perfilan intenciones de abordar campos más profundos. La finalidad de este trabajo en conjunto debe recaer en la comprensión del panorama general que rige en el sector, es decir, entender sus múltiples factores que causan estos problemas, que generalmente, son mal entendidos, generando soluciones específicas o puntuales que limitan el manejo del problema global. En este sentido, las acciones implementadas y lideradas por Artesanías de Colombia en compañía con las demás entidades nacionales, siguen enmarcándose en un trabajo sistémico, donde si bien han ampliado el foco de acción fuera de lo material y proyectual, las soluciones implementadas en las problemáticas encontradas, siguen siendo específicas sin cruzar la red de relaciones. Como puntos a seguir, antes de empezar a trabajar, se hace necesario incrustarse en el sistema a intervenir, es decir involucrar a las personas que se desea apoyar y comprender lo que les hace falta para desarrollar estrategias que faciliten la elaboración de mapas de investigación que guíen a la identificación de problemáticas para luego proponer ideas o soluciones estratégicas (Dhale, 2015).

En la actualidad Artesanías de Colombia tiene sobre sus hombros la responsabilidad puntual del bienestar del sector artesanal, por lo tanto es la que mejor conoce las problemáticas del sector y busca resolverlos en compañía de otras entidades que considere que pueden aportar, sin embargo es un mecanismo interdisciplinar ya que sólo busca resolver un problema puntual con apoyo de un área o disciplina experta en ese problema. Por ejemplo, si se considera que los artesanos deben formar parte de un programa de capacitación técnica en corte, confección y costura, se contacta al SENA para que brinde ese programa en la comunidad, pero ignoran otras circunstancias de índole social y cultural, como los motivos por los cuáles no asisten o desertan de este tipo de cursos. Por otra parte, se resalta la labor de las distintas instituciones que intentan resolver las diversas problemáticas del sector artesanal. Es evidente que han empezado a ampliar la mirada hacia otros aspectos distintos de los ámbitos proyectuales y productivos, para ocuparse de otros más complejos. No obstante, resultaría beneficioso que avancen en sus esfuerzos hacia un mayor nivel, en el que, los profesionales implicados tengan más trabajo de campo, interactúen con la gente para identificar y entender los problemas desde una perspectiva más cercana. De esta manera, puedan incorporarse al campo artesanal relacionándose directamente con sus actores: los artesanos. 
El planteamiento de soluciones y estrategias deberían hacerse contemplando una idea de futuro a mediano/largo plazo, de lo contrario, sería una solución o estrategia temporal. De acuerdo a Margolin (2007), establecer cambios en estos tiempos de ritmos acelerados, es una tarea a la que muchos profesionales e incluso diseñadores no están acostumbrados ni preparados. Si un diseñador pretende ser un agente de cambio debe enfocar su curso de acción considerando el pasado y el presente, ya que de ellas provienen los determinantes posibles hacia el futuro:

Planificar eficazmente en el presente requiere una visión de lo que el futuro podría y debería ser. Utilizo tanto el condicional "posible" como el prescriptivo "debería" para sugerir, en el primer caso, que el futuro se basa siempre en la contingencia de las elecciones humanas y, en el segundo, afirmar que estas elecciones deben ser impulsadas por una consideración de lo que debe hacerse (Margolin, 2007:5).

Ante la visión del futuro derivada del "podría ser” o “debería ser”, el autor distingue entre escenarios futuros predictivos y prescriptivos, es decir, escenarios basados en lo que podría suceder (predictivo), o escenarios basados en lo que debería suceder (prescriptivo). Para estas circunstancias el despliegue de mecanismos o de gestiones que se deseen implementar para resolver el problema, debe estar fundamentado en uno de estos dos escenarios, de esta determinación depende su trazabilidad y trascendencia, teniendo en cuenta que "los escenarios predictivos tienden a ser pragmáticos, mientras que los prescriptivos son idealistas" (Margolin, 2007:6).

Para Irwin (2014) el Diseño para la Transición es una nueva área práctica que se propone considerar cuestiones sociales, ambientales y económicas instando, especialmente a las nuevas generaciones de diseñadores, a pensar y a llevar sus respuestas hacia horizontes más amplios y de futuros duraderos. De acuerdo con Di Bella (2018), esta perspectiva se traduce en mayores desafíos para los diseñadores, quienes desde una formación generalmente lineal y comercial, inexpertos en el manejo de tales situaciones, deben considerar esta reconceptualización para "comprender al diseño ya no como parte de un proceso lineal centrado en el usuario o un cliente, sino como un tejido de relaciones entre muchas partes interesadas" (Di Bella, 2018: 189). Desde esta concepción se afirma que la tarea del diseñador era antes más específica de lo que hoy se requiere, y en consecuencia, se vienen reconfigurado sus discusiones éticas, pasando de ser modestas como el discurso formal y función mecánica del producto, hacia otras más humanas (Margolin, 2007:14).

\section{Producción artesanal Zenú: Hacia una visión sostenible}

El desglose de situaciones/problemas de la comunidad Zenú que se ha compilado a lo largo de este trabajo y su conexión en la red de problemas complejos (wicked problems) involucra a diversas Instituciones gubernamentales, a expertos profesionales y, por supuesto, a los artesanos. Los caminos de solución a estas problemáticas en evolución, desde la reflexión derivada de la propuesta del Diseño para la Transición, indican que deben ser 
eficientes, aunque el desafío recae en abordar tres cuestiones fundamentales: (1) la coordinación de todas las partes involucradas, (2) el apoyo en el cambio de comportamiento individual e iniciativas en la innovación social, y por último, (3) asegurar que las soluciones cobijen a todos los sectores involucrados incluidos el medio ambiente (Irwin, 2017: 10). El abordaje de estas cuestiones implica que muchas veces las relaciones entre las partes interesadas sean problemáticas ya que hay distintas maneras de pensar y de visionar, es allí donde el manejo de la situación se vuelve compleja ya que se debe ceder, aceptar o cambiar opiniones, posturas, creencias o perspectivas que a menudo suelen ser barreras que entorpecen el desarrollo del proceso, pero que, si se tiene disposición y voluntad, estas mismas barreras pueden ser oportunidades para el cambio y para la innovación.

Existe una necesidad de concentrar los esfuerzos y el trabajo en lograr una visión sostenible que trascienda en un período de largo plazo, donde se debe explorar los escenarios donde se requieren nuevas visiones de futuro: "el hecho de pasar al cómo podrían/deberían ser en el futuro (diseño especulativo) requiere no solo de otros nuevos conocimientos y herramientas que permitan entrenar la mente en la reconceptualización y generación de visiones anticipatorias de esos nuevos escenarios sostenibles" (Di Bella, 2018:195-196). Para ello la metodología no radica en identificar problemas y describir soluciones, sino imaginar cómo el futuro debería ser: "No se puede diseñar soluciones para un futuro que no ha sido imaginado" (Irwin, 2017:16). Parte de estas visiones a largo plazo se fundamentan en un estilo de vida sostenible, es decir "formas de vida que permiten a las personas satisfacer sus necesidades y aspiraciones personales, garantizando que las generaciones futuras también puedan hacerlo" (Irwin, 2017:12).

Concentrando esfuerzos para construir un mejor futuro para los zenúes, Artesanías de Colombia ha propuesto varios esquemas en distintos períodos, en los que se compilan distintos mecanismos bajo la figura de seminarios, talleres de creatividad, asesorías, dirigidos a posicionar los productos artesanales en el mercado, incentivar la creatividad de los artesanos y evaluar en términos de diseño las propuestas desarrolladas por ellos, respectivamente. Bajo esta política, se evidencia que es una estructura de trabajo que se fundamenta en la generación de propuestas en relación a los nuevos modelos y tendencias que marca el mercado. Sin embargo, dentro de los objetivos específicos planteados en el Manual de Diseño de Artesanías de Colombia en 2002, se evidencia un importante cambio en la estructura de trabajo donde se apuntan a que las intervenciones se sustente bajo límites de acción y respeto por los recursos. Tales objetivos son:

1. Definir los límites de acción de las actividades de diseño aplicado a la artesanía; 2. Involucrar el concepto del diseño en la producción artesanal; 3. Fomentar programas de formación y especialización en el área de diseño aplicado a la artesanía; 4.Coordinar acciones dirigidas a fortalecer la identidad del producto artesanal; 5 . Propender por la conservación, uso y renovación de los recursos naturales (Artesanías de Colombia, en Barrera y Quiñones, 2006: 58).

En comparación a los objetivos planteados en el Manual de Diseño de 1998, es importante resaltar que para la actualización de este documento en 2002, se delimitan las acciones del Diseño aplicado a la producción artesanal, es decir, que ya existe una conciencia acerca 
de las intervenciones que se ejecutan en la comunidad y que es necesario tomar responsabilidad frente a estos procesos. Además, en el quinto objetivo propuesto, se apuesta a tomar una postura consecuente con el medio ambiente desde el manejo y conservación de los recursos naturales. La consideración de estas pautas en los objetivos de acción en el trabajo con comunidades artesanas es un punto importante a resaltar porque se empiezan a vincular con lineamientos del diseño responsable y el diseño para la innovación social, ampliando los terrenos de acción y de impacto. No obstante, el desarrollo de las visiones de futuros sostenibles comienza a construirse cuando se trabaja en relación y sincronía con la comunidad, es decir, cuando el "actor externo" busca inmiscuirse y comprender las nociones tanto particulares como colectivas de las personas, cómo las trabajan y bajo qué mentalidad las construyen. Del mismo modo, la comunidad, como "actor natural", tiene

La oportunidad de reflexionar y aprender sobre su propio pensamiento. Pasando de este proceso general para considerar imaginarios futuros específicos; emergiendo las expectativas, aspiraciones y creencias de una comunidad sobre sus propias perspectivas pueden informar el desarrollo de visiones más profundas y más robustas (Lockton y Candy, 2018: 31).

Partiendo de estas nociones, se abre un espacio para reflexionar e imaginar un futuro para el resguardo indígena Zenú ¿qué se esperaría para ellos? ¿Desde qué otros caminos de intervención se pueden actuar? ¿Cómo debería ser su situación o su ideal? Es importante resaltar que las siguientes propuestas emergen en función de ser ideas disparadoras producto de encarnar una sensibilidad ideal del futuro deseable y de los pasos necesarios hacia una transición sostenible de la producción artesanal Zenú. Si bien se han descrito y esbozado las problemáticas que aquejan a la comunidad en estudio, no se considera que se tenga la potestad de proponer soluciones concretas y certeras hacia un nuevo paradigma ya que no se es parte activa del campo artesanal. Además, la incursión teórica realizada a nivel personal sobre ésta nueva reconceptualización del Diseño aún es incipiente, por tanto resulta difícil crear visiones a futuro sin contar con experiencia práctica de las teorías estudiadas.

Para tener referencia de la aplicación de estas teorías, en la sección Teaching Design for Transition (Enseñando Diseño para la Transición), del trabajo de Mouchrek y Krucken (2018), se exponen varios casos ejemplo donde se exploran los procesos de diseño centrados en el cambio social y en el apoyo de transiciones hacia la sostenibilidad. Uno de ellos es la conferencia anual que se realiza en Italia: "by design or by disaster", que considera que el diseño puede "contribuir fundamentalmente al desarrollo de un mundo sostenible al considerar patrones de producción, consumo, eliminación, comunicación e interacción social", ya sea en formas sostenibles o insostenibles. La idea de "by design or by disaster" refuerza exactamente este punto: que el diseño consciente puede, de hecho, fomentar un sistema eco-socioeconómico, resiliente y equitativo (evitando desastres, o evitando la creación de patrones insostenibles)" (Mouchrek y Krucken, 2018: 129). El objetivo de estas conferencias es arribar a una solución práctica donde el problema es compartido y abrir un espacio donde sus participantes puedan manifestar y presentar sus ideas para luego ser discutidas y evaluadas en conjunto. Partiendo de esta idea, se podría hacer una invitación 
a Artesanías de Colombia, para que garantice un espacio dentro de su calendario anual, similar al que desarrolla para la realización de la feria Expoartesanía (plataforma de promoción, divulgación y proyección del sector artesanal colombiano hacia mercados nacionales e internacionales) y bajo la figura de conferencia, congreso o simposio, se convoquen a varios participantes de distintos perfiles con experticia en el campo artesanal para que se reúnan, expresen y expongan las problemáticas del sector y con ellas los distintos aportes por medio de ideas disparadoras. De este modo se reflejaría una fuerte intención por parte de la principal Institución colombiana que vela por el sector artesanal del país, en atender otros asuntos fuera del ámbito comercial, económico o mercantil.

A continuación se esbozan otras ideas disparadoras sustentadas en distintas herramientas y teorías que pueden ser utilizados como guía para implementar algunas posibles primeras acciones. Sin embargo, antes de exponerlas es necesario tener presente que los sistemas son dinámicos e interactivos, por lo que resulta preciso comprenderlos como procesos, en lugar de verlos como solo cosas o aspectos. Para Lockton y Candy (2018),

Diseñar para las transiciones es ambicioso. Es inherentemente multiescalar e inter-transdisciplinario. Sus posibles practicantes necesitan formas de compartir lo que están haciendo, lo que parece funcionar, y en esta etapa las herramientas apropiadas de pensamiento y aprendizaje están obligadas a ser modulares y fragmentarias en lugar de abarcarlo todo. Se sugiere que esta noción de patrones o lentes - una colección modular y de despliegues de enfoques para examinar, pensar y actuar en situaciones diversas- encierran una parte del potencial del desarrollo de la práctica del diseño para la transición (Lockton y Candy, 2018:29).

Para abordar el aspecto "visionario" del Diseño, los autores utilizan la metáfora de la "visión" de una manera deliberada para explicar siete "lentes" o siete maneras de ver, que ellos han definido como potencialmente útiles para desarrollar futuros sostenibles, y son: Lentes, Imaginarios, Backcasting, Materia oscura, Circularidad, Futuros experienciales, y Nuevas metáforas (Lockton y Candy, 2018). Eligiendo como lente a la metáfora, se ha intentado "mirar" a través de ella, las propuestas que se exponen a continuación para visionar el futuro Zenú.

Inicialmente, a través de la matriz del Social Pathways Design se propuso, modestamente, una serie de acciones y mecanismos como disparadores de posibles soluciones desde los tres niveles de impacto (individual, sistémico y cultural) en relación con un futuro sostenible para los indígenas Zenú (Ver Figura 13). La ubicación de los distintos mecanismos en estos tres niveles de acción sirve para organizar y esclarecer los alcances en cada nivel, para realizar evaluaciones más concretas acerca de la contribución que tendría dentro del problema y también de servir como guía o checklist de las acciones a implementar hasta lograr el mayor nivel o el ideal a alcanzar. Trabajar desde las nociones del diseño para la transición implica establecer desde qué escala se pretende abordar la situación y cuáles serían los impactos que se esperan tener. Así se determina si la intervención a ejecutar se ubica dentro de una escala pequeña como aquellas soluciones independientes propuestas por una persona (diseñador, por ejemplo), o se enmarcan dentro soluciones de mediana y 


\section{PATHWAYS in SOCIAL DESIGN}

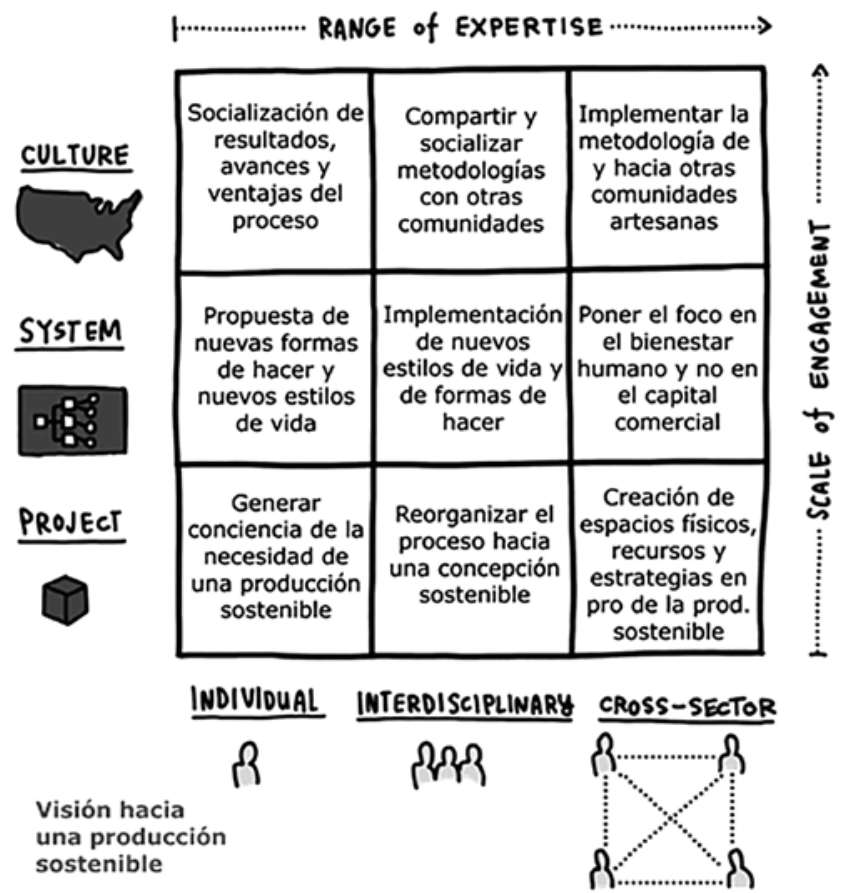

Figura 13. Matriz Social Pathway Design, hacia una producción artesanal sostenible. (Elaboración Propia)

gran escala como aquellas al nivel del sistema, que requieren de un trabajo interdisciplinar, o ser más ambiciosos, en el despliegue de acciones que promuevan transformaciones culturales que impliquen cruces entre los distintos sectores involucrados. La determinación de la escala es directamente proporcional a su complejidad y nivel de impacto.

En la matriz de impacto se ubican los pasos para plantear nuevas formas de vida autoorganizadas y conectadas a múltiples escalas (hogares, barrios, regiones, países, planeta) cuyo desarrollo se oriente al planteamiento de estrategias que estimulen nuevos estilos de vida, nuevas formas de ser y de hacer, enfocados en el bienestar de la comunidad y no solo volcados hacia intereses comerciales. En los párrafos siguientes se desglosará con más de- 
talle las ideas que se ubican en cada casilla de la matriz. Si bien son estrategias basadas en el Diseño para la Transición (Irwin, 2012,2014, 2017), los primeros niveles corresponden a acciones a nivel individual o núcleo familiar con poco impacto pero que de igual manera aportan, hasta llegar a los últimos niveles de acción donde se promueven el espíritu de cooperación, interdependencia y aprendizaje mutuo entre otros sectores afines (Sachs en Kossoff, 2018: 52), afianzando de esta manera las relaciones entre lo local y lo global. Al proponer diálogos, socializaciones, implementaciones y compartir avances/ resultados de metodologías con otras comunidades artesanas en los más altos niveles de acción de esta matriz, se da cuenta que los lazos simbióticos entre lo local y lo global apuestan por edificar una mejor relación ya que: "es un error dicotomizar el cosmopolitismo y el localismo contemporáneo, ambos abogan por una relación mejorada de lo global y lo local y tienen el objetivo común el abordar los problemas causados por la globalización" (Kossoff, 2018:56), por lo tanto se hace necesario vincular a otras comunidades a nivel nacional e incluso contactar a organismos de otros países que amparen el trabajo artesanal, para buscar patrones similares que puedan transformarse en incipientes estrategias o el principio de las soluciones.

En este sentido, se sugiere trabajar en el campo artesanal en un ámbito global, de esta manera se identifican, se documentan y se comparan las problemáticas de distintas comunidades originarias. Así las convergencias y divergencias entre ellas se podrían analizar para la instauración de futuras políticas culturales que erradiquen sus puntos de conflicto. Además, sería muy enriquecedora la confluencia con otros organismos similares a nivel latinoamericano para poder efectuar una retroalimentación de problemáticas, de soluciones y de políticas que puedan implementarse o mejorarse en los distintos países.

Intentando idealizar un circuito sostenible para la comunidad Zenú (primeros niveles de la matriz Individual/proyecto), se plantea el interrogante de cómo se podrían resolver las problemáticas que aquejan a la etnia, a través de mecanismos que prioricen nuevas visiones en términos de estilos de vida sostenibles, que se perfilen hacia transiciones sociales, no desde lo económico, sino desde perspectivas que se fundamenten en la eficiencia y la colaboración, mismas que hacían parte de su filosofía antes de la Conquista Española, ya que no diferirían con las que se podrían implementar en la etnia Zenú como motivantes para su gestión e implementación en el futuro desde el hogar, modos de producción y comunidad.

La elaboración de artesanías es un proceso que utiliza recursos naturales que se asocia a un contexto particular de una comunidad artesana, cuyo objetivo es transformar tal recurso en una expresión material y simbólica/funcional llamada artesanía, de modo que lo artesanal fusiona procesos productivos con aspectos culturales en función del uso de recursos naturales, los que muchas veces, como se ha expuesto, han sido vulnerados por las dinámicas del mercado y lo global. (Pacheco, Gómez y Barrero, 2009 :210). Sin embargo, como la producción artesanal Zenú se hace desde el hogar (casa taller), la transformación de los recursos naturales en artesanías se debe realizar con cierta responsabilidad y lógica ambiental. Es el caso de manejar eficientemente los recursos naturales para la elaboración de artesanías y enseñar e infundir, en los más pequeños, no sólo las tradiciones ancestrales, sino las acciones pertinentes para el buen manejo de la palma y los demás recursos como las hojas y flores que se usan como colorantes naturales. Si bien en la labor artesanal los re- 
cursos naturales son los insumos que predominan en su producción, hay otros artificiales como los colorantes químicos que se deben evitar ya que causan daño a la salud y al medio ambiente, ya que la productividad ecológica "hace referencia, primero, a la organización productiva en función de los recursos naturales claves para la producción de las artesanías y segundo, al control de los efectos contaminantes del proceso productivo" (Pacheco, et. al 2009: 208). Lo ideal es que de la mano de expertos, se estructuren acciones y mecanismos que guíen a cada núcleo familiar indígena para que desde las casas taller determinen los recursos que necesitan, en la cantidad suficiente y de forma sostenible para la producción de sus artesanías. Así se optimiza y se reduce el consumo de la materia prima utilizada para la confección de los distintos productos (Ver Figura 14).

Lograr esta visión sólo es posible, cuando la construcción de estos imaginarios comienza con la sensibilización,

Usar el lente de los imaginarios ayuda a sensibilizarnos tanto a nosotros mismos como a los demás para el funcionamiento y la dinámica de qué y cómo imaginamos los sistemas en los que estamos, como son y cómo podrían ser. En esta área, los Diseñadores para la Transición pueden desempeñar un papel valioso como traductores o mediadores entre mentes e ideas, y el mundo; entre situaciones actuales y posibles nuevas formas de vivir (Lockton y Candy, 2018:32).

Retomando hábitos de su sistema sociotécnico antes de la llegada de los españoles, es decir, mirando con el "lente" del backcasting (Lockton y Candy, 2018) para estudiar lo pasado y extrapolarlo al futuro, en esta instancia se podría proponer que cada familia cultive con sus propios medios la cantidad y el tipo de alimento que sea capaz de sembrar, para luego ser llevado e intercambiado de manera comunitaria con sus vecinos, amigos y/o demás familiares cercanos. Esta propuesta se sustenta en una economía campesina que "se basa en la búsqueda del equilibrio entre producción y consumo, de tal forma que adquiere ingresos adecuados a las necesidades de la unidad familiar" (Pacheco, et.al 2009: 208). La idea se encamina hacia una figura de "huerta social" donde haya una dinámica de intercambio de alimentos que se cultiven en la región entre las familias, así cada unidad familiar del resguardo tiene un poco de cada cosa; papa, yuca, maíz, etc. (Ver Figura 15).

Algunas tendencias orientadas a modificar los estilos de vida se pueden relacionar con los principios de la economía circular, que busca replantear el esquema de economía lineal (producir, consumir y tirar) en otra donde se reutilice, lo que muchas veces es considerado basura, como insumo para fabricar nuevos productos (Stang, 2017, 04 de junio, $\mathrm{La}$ Nación). Es decir un modelo cíclico donde no existen residuos ya que son utilizados como alimento o materia prima de otra producción. De esta manera, se cambia el paradigma de explotar, producir, usar y desechar, por reducir, reusar y reciclar.

1. Los cambios hacia el consumo eficiente (gastando menos), el consumo diferente (cambios a bienes de alta calidad y servicios), y el consumo suficiente (reduciendo el consumo material) demuestran oportunidades para los modos sostenibles de utilizar productos y servicios; 2. El consumo colaborativo 
(compartiendo, el cambio, el comercio, etc.) revela un cambio en preferencias lejos de la propiedad de bienes para "tener acceso" a bienes y servicios y de ser a consumidores pasivos a la acción de hacerse los coproductores de bienes y servicios (la agricultura p.ej. urbana; crecimiento de su propio alimento); 3 . El cambio en las costumbres comportamientos desde la casa para conservar la energía es una conciencia creciente hacia el cambio hacia modos más sostenibles de vida (Irwin, 2017:12).

Para migrar hacia un modelo de economía circular se debería iniciar por tener presente todas las fases de la producción y analizar el impacto que tiene a nivel sociedad y medio ambiente. Existen algunos principios que configuran el funcionamiento de la economía circular, entre ellos: la ecoconcepción, la ecología industrial y territorial, la economía de la funcionalidad, el segundo uso, la reparación y el reciclaje (Fundación Economía Circular, sf). Teniendo en cuenta los modos de producción Zenú y los tipos de productos que elaboran, se hace interesante trasladar algunos de estos principios como primeros pasos para adoptar este nuevo modelo económico. Por ejemplo, el principio de la ecoconcepción, como se había propuesto en párrafos anteriores, se debería planificar desde las casas (casa taller) de la mejor manera para minimizar el impacto ambiental que causa el uso de recursos (palma y colorantes) en la producción de artesanías. Además, sería interesante que los artesanos empezaran a indagar en nuevos tejidos o trenzados que requieran menos consumo de caña flecha para integrarlos en la pieza, bien sea bajo el formato de apliques, o en lugares que no requieran de tanta estructura y rigidez. Se hace hincapié en este punto, porque las artesanías Zenú se destacan por la rigidez y estructura que aporta el trenzado de metros en caña flecha, pero analizando el producto en su etapa de concepción se puede determinar que hay partes que (problablemente) puedan no requerir de tal rigidez. Por ejemplo, el cuerpo de un bolso es necesario que sea estructurado, para que forma como diseño se puedan apreciar, pero sus asas no requieren que sean tan rígidas, y por lo tanto utilizar nuevos tejidos que requieran de menos caña flecha, o también en el caso de las billeteras donde se pueden integrar estos nuevos tejidos en forma de apliques.

En cuanto a la siembra de la palma caña flecha, se propone que el Estado restituya y otorgue tierras comunitarias a los indígenas, quienes se deben organizar para su cuidado y explotación en el sembrado de la palma, en aras de buscar la optimización en el uso de este recurso y compartir los esfuerzos que su cosecha requiera. Es una labor que se basa en el principio de ecología industrial y territorial de la economía circular, que debe hacerse entre varios miembros de distintas familias (aprovechando y compartiendo su saber empírico sobre los recursos naturales) para dividirse la cosecha por partes iguales y poder trabajarlas. Es un método que beneficiaría a muchos artesanos ya que se podrían reducir los altos costos en que se consigue en la actualidad la caña flecha (Ver Figura 16).

Las propuestas del manejo de consumo de recursos naturales y energéticos, la conservación de la palma y el trabajo en conjunto y colaborativo de los cultivos, son ideas que se pueden manejar a nivel del núcleo familiar que además se deben complementar como propuestas modulares y fragmentadas ("lentes") que conformen un despliegue de enfoques para indagar, pensar y actuar en diversas situaciones (Lockton y Candy, 2018). 


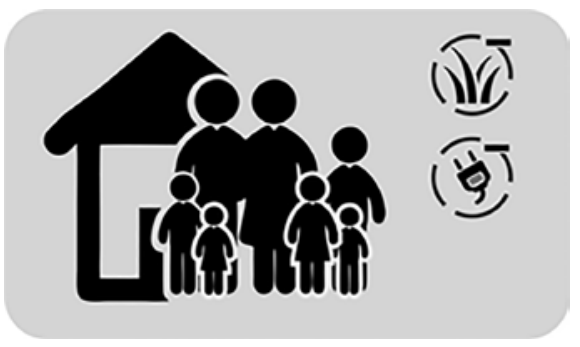

Figura 14.

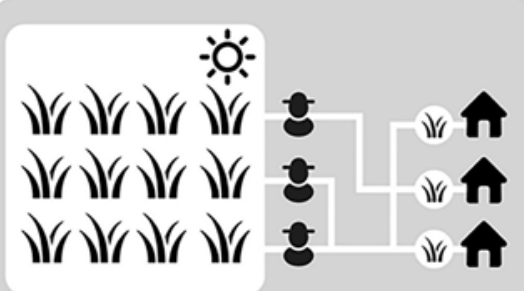

Figura 16.

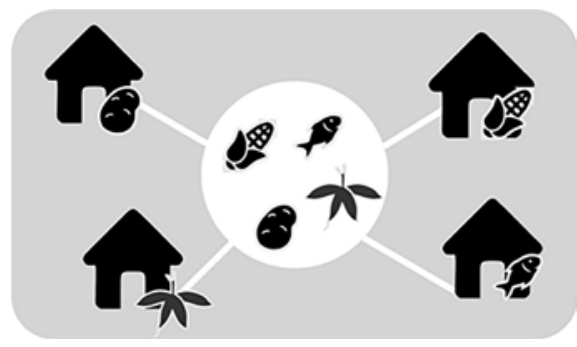

Figura 15.

Figura 14. Visión sostenible del hogar para la etnia Zenú (Elaboración propia). Figura 15. Visión sostenible de cultivo de alimentos para la etnia Zenú (Elaboración propia). Figura 16. Visión sostenible de siembra de la palma caña flecha (Elaboración propia).

Entre otras ideas, se encuentra el desafío de indagar y concebir nuevos modelos de negocio basados en la sostenibilidad (Di Bella, 2018; 192), en este punto es necesario pensar en nuevas formas de comercialización dirigidas hacia una economía de funcionalidad que mude el foco de una venta de producto a una venta de servicio. Hay varios modelos de negocios que se acogen a esta modalidad de arrendamiento, y consiste en que el cliente paga por el uso temporal del producto y cuando éste sea devuelto y haya cumplido su ciclo la empresa manufacturera lo repara, o le da un segundo uso, o en su defecto, recicla las partes que aún se puedan utilizar (Fundación Economía Circular, sf.). Replantear el modelo de comercialización Zenú hacia esta modalidad de economía de funcionalidad puede resultar muy beneficioso tanto para los artesanos como para los consumidores o clientes del público en general, recordando que el cultivo de la palma es una de las principales problemáticas que aqueja a la producción artesanal Zenú, siendo que es costosa conseguirla por la falta de tierras para sembrarla y por los fuertes y amplios veranos, circunstancias que se reflejan en los precios de las artesanías, en especial en el sombrero vueltiao. 
Visionar un modelo de arrendamiento de sombreros vueltiao es una propuesta que debe ser puesta en consideración, y hacer pruebas piloto (futuros experienciales, Lockton y Candy, 2018) que podrían intentarse en las principales fiestas patronales, populares y ferias para aprovechar la confluencia de asistentes y turistas que quieran lucir este símbolo de Colombia a un menor costo que si lo compraran. Esto podría afianzar el flujo de caja en las finanzas de los artesanos, ya que abre la posibilidad ampliar el grupo objetivo de clientes, y que estos últimos tengan la oportunidad de portar un sombrero original hecho por los propios indígenas Zenú, evitando que compren o adquieran una réplica hecha en otro material. Como última acción, se propone la creación de centros de acopio en las principales ciudades del país cuya principal función sea recibir aquellas artesanías que estén dañadas y/o defectuosas para que posteriormente sean tratadas o reparadas por artesanos, y así ampliar su uso o ser reutilizada en otros fines.

A partir de proponer nuevos comportamientos o nuevas formas de ser y de hacer, se requiere de una auto-organización del sistema, entendiéndose como una oportunidad para la evolución, experimentación, prueba y adopción de nuevos patrones (Meadows, 1999). Las transiciones y las visiones hacia futuros sostenibles requieren de cambios en hábitos, costumbres, entendimiento y adopción de nuevos esquemas, que inciten el anexo, eliminación o reorganización de cuestiones establecidas dentro de la estructura del sistema. Para Meadows (1999), un sistema que se auto-organiza y evoluciona, prolonga su estancia en este mundo altamente variable. Pero ¿̇será esta variabilidad la que condicionan las transiciones o son los diseñadores quienes les dan forma? Para Lockton y Candy (2018) cuando se "diseña para las transiciones dentro de contextos sistémicos, vale la pena reflexionar sobre la circularidad de los esfuerzos en los que estamos comprometidos: ¿en qué medida las variables en las que creemos nos están moldeando las acciones que tomamos sobre ellas?" (Lockton y Candy, 2018:38).

Es necesario evolucionar para no desaparecer como sistema, por lo tanto es preciso conocer hacia qué objetivo o grupo de objetivos, se están perfilando los cambios o experimentos que se implementan. Por ello la definición de los objetivos es importante ya que son ellos los que direccionan su cumplimiento y/o consecución. Estructurar un circuito sostenible para los zenúes, sería un objetivo que tendría un alcance en profundidad, según sean los intereses que lo fundamenten, es decir, es diferente plantearse el mismo objetivo si se pretende mejorar su calidad de vida, reduciendo los índices de pobreza y desempleo, a que se pretenda asegurar y cuidar a largo plazo todo su circuito a través de estrategias que otorguen un reparo real para la etnia.

El anterior listado de propuestas lograría su cometido si existiese disposición para nuevas formas de ver y nuevas de hacer que pueden guardar discrepancias con los paradigmas de cada quién. Cambiar, evolucionar, transformar o adoptar, son pautas difíciles de digerir ya que trasgreden al paradigma de todo un colectivo de personas, que es complicado de cambiar, pero no existen límites cuando esto sucede (Meadows, 1999). Es probable que el cambio de paradigma sea más complicado cuando se trabaja bajo un sistema de población indígena, ya que el manejo es diferente y se debe tratar con cuidado, ya que poseen costumbres muy arraigadas que se deben conservar y es difícil que se cambien, pero que también se deben migrar hacia otros paradigmas más afines al dinamismo de estos tiempos para que como comunidad no desaparezcan. 
Para el caso Zenú, si no se toman las decisiones correctas y si las intervenciones que se realizan para la resolución de sus distintas problemáticas no son las precisas, probablemente su futuro sea incierto, y se esté labrando el camino hacia la desaparición de su etnia. El resultado puede ser otro, si se toma conciencia al plantearse el interrogante si los mecanismos de intervención propuestos conducen a una hecatombe o un manejo responsable de dimensiones importantes, como la social, ambiental, cultural y económica, es decir, si todo el sistema está siendo cuidado.

Como primer nivel de acción "individual/proyecto" (ver cuadro de social pathway), la implementación de los planteamientos propuestos para la concepción de nuevos estilos de vida, sería la socialización con la comunidad de la necesidad, ventajas y futuros resultados que se lograrían de ponerse en práctica. Mantener un flujo comunicativo constante con ellos, aseguraría tener actualizada la información sobre el estado de este proceso, creando conciencia, compromiso y hábitos en los indígenas. Además, parte importante de la inclusión indígena en estos procesos, es la construcción democrática a través de actividades participativas nacidas en la comunidad, que estimulen el imaginario colectivo aportando ideas con mayor innovación, ya que ellos, como principales actores, saben cuáles son sus necesidades y pueden plantear mecanismos más eficientes para satisfacerlas (Baron, 2018: 165). Ahora, cada intervención diseñada para actuar desde lo local, tendrá repercusiones en niveles más amplios, por ejemplo, a nivel nacional o global. Por ello, más allá de implementar cualquier mecanismo de acción, es prudente entender el comportamiento que se tendría bajo ellas y qué efectos generaría en otros sistemas de la sociedad.

Un Diseñador para la Transición debería ser más efectivo prestando atención a estos contextos (en evolución) tanto como a la "cosa" en sí, al diseñar con una visión de las formas en que los aspectos (a menudo en gran parte invisibles) de los sistemas trabajarán para apoyar o restringir el cambio ("lente de materia oscura”, Lockton y Candy, 2018: 35).

Sería contraproducente diseñar políticas o reglas por los zenúes y para los zenúes sin tener en cuenta los flujos de información y retroalimentaciones que provengan de otros sectores. Por tanto, en niveles más altos de acción "sistema/cultura" (ver cuadro social pathway) se habla de socializar y compartir metodologías y maneras de trabajar para conocer el saber hacer de otras comunidades o sectores afines que puedan aportar al saber hacer particular. Estas nociones se basan en el localismo cosmopolita:

El localismo y el cosmopolitismo deben integrarse para abordar sus respectivas limitaciones. Además, cada discurso aborda conceptos que son relevantes al otro. Bajo los temas generales de resiliencia y rehabilitación, el localismo plantea preguntas sobre necesidades, lugar y comunidad que son relevantes para el tema de la presencia humana colectiva en el planeta. El cosmopolitismo plantea preguntas sobre la humanidad y la convivencia del planeta, sobre el significado de la otredad y apertura, y sobre la coevolución de las culturas; las respuestas a todos estos ayudarán forma estilos de vida localizados (Kossoff, 2018: 56). 
Esta postura, marca una perspectiva interesante de la relación, muchas veces consideradas como desconectadas, entre si (local y global). Las nuevas acciones que se dirijan al bienestar de una comunidad indígena no deben ser entendidas como mecanismos que van a abolir las costumbres de una cultura en particular, sino que van a construirlas en afinidad y de acuerdo a los cambios contextuales presentes en el planeta.

Con lo que se viene desarrollando, se ha intentado demostrar que hay estrategias que distan de aquellas metodologías que integran racionalización, planificación, innovación y desarrollo de nuevos productos, como bases fundamentales para el trabajo diseñador/artesano que buscan lograr un posicionamiento únicamente en el mercado. Por el contrario, existen otras que comprometen al diseñador a cumplir un papel social, donde desempeñe un rol de acompañante en el proceso de aprendizaje del artesano y a su vez, que pueda considerar y deba intervenir y gestionar soluciones a problemáticas de tipo social, económico y ambiental, las que regularmente aquejan a este tipo de poblaciones vulnerables. Sin embargo, ampliar el campo de acción del diseño a dimensiones más complejas es un compromiso y una responsabilidad que se ha venido gestando y concientizando por medio de la experiencia que se ha adquirido a través de generaciones de diseñadores, quiénes aún deben aprender a ver y resolver estos problemas, desde una perspectiva fuera del diseño, para así desarrollar nuevas capacidades y destrezas en cuanto a la reflexión y al cambio que dichas situaciones requieren (Irwin, 2014). En este sentido, se debe tomar conciencia que el trabajo del artesanado es diferente al industrial y que el diseño tiene el compromiso de implementar metodologías de gestión que vayan dirigidas a ellos. En consecuencia, el trabajo sinérgico entre los distintos actores, garantiza la viabilidad, trascendencia y trazabilidad de una solución que impacte de manera positiva directamente sobre los más vulnerables, en este caso, los zenúes.

\section{Conclusiones}

Existen muchas investigaciones y estudios de referencia sobre las artesanías y su modalidad de producción en las distintas comunidades que la producen. El oficio artesanal ha sido estudiado bajo diversas perspectivas: desde lo antropológico, desde su modalidad productiva, desde su estructuración y división del trabajo dentro del núcleo familiar, desde las innovaciones de sus técnicas, hasta su comercialización. Es indispensable identificar los anteriores aspectos mencionados y conocerlos en la etnia del caso de estudio, ya que contextualiza y enmarca la situación particular de la investigación. Sin embargo, este proyecto pretende acrecentar los estudios acerca de la producción artesanal desde la perspectiva de los flujos culturales y el dinamismo constante de la actualidad y su influencia en las modificaciones que se producen sobre las artesanías, tomando como objeto de estudio al sombrero vueltiao. Desde este enfoque, el objetivo de este trabajo consistió en trazar un recorrido cronológico de sus transformaciones, que en mayor o menor medida, ha sido influenciada por los lineamientos de cada época. Este abordaje apuntó a integrar instancias sociales, ambientales y económicas que influenciaron su producción, cuyos efectos se derivan en transformaciones que responden a su momento histórico de elaboración y a las demandas cambiantes del mercado. Es en este punto donde radican los mayores apor- 
tes de esta investigación, ya que a través del sombrero vueltiao se fundamentó, con bases teóricas, cada una de sus modificaciones, aportando una guía de estudio que se puede replicar (quizás en el estudio) de otros objetos artesanales si se analiza cada una de sus fases, transformaciones y transiciones.

También permitió comprender las distintas instancias en las que se inscribe el diseño, su vínculo con el oficio artesanal y la influencia que tiene la posmodernidad y sus escenarios relacionados con el hipercapitalismo, la industria cultural y el consumo sobre este tipo particular de producción. Asimismo, el análisis de la relación arte/artesanía/diseño permitió establecer que las antiguas discusiones sobre las consideraciones y las valoraciones de las piezas artesanales en relación a los enunciados de las Bellas Artes son ideológicas. Tanto las Artes, como las artesanías y el diseño se encuentran inmersas en procesos sociales dinámicos que no se pueden ignorar. Por lo tanto, es necesario evaluarlas dentro de su mismo campo para poder dilucidar sus cruces y convergencias, es decir, entender los objetos pertenecientes de determinado campo, como objeto producto del saber hacer o del proyectar (Bovisio, 2002).

Por otra parte, con los distintos ejemplos expuestos se puede ver la manera en cómo los lineamientos de estos tiempos, a través de los medios de comunicación y de la tecnología, afectan de igual manera a las comunidades indígenas. Se suele creer que ésta porción de la sociedad, en su mayoría asentadas en zonas rurales consideradas muy arraigadas a sus tradiciones culturales, son ajenas a estos cambios. La realidad es otra. El grupo étnico Zenú tuvo cambios significativos a lo largo de toda su historia, los parámetros productivos de sus artesanías fueron transformándose. Desde la década de los 70, cuando Artesanías de Colombia empieza a incursionar en este sector, el entramado de este acompañamiento se dirige a fomentar la elaboración de objetos artesanales con fines mercantiles. Tal situación implicó que agentes e instituciones externas a la comunidad se vinculen con ellos provocando que nuevas maneras, nuevos procesos y que nuevas costumbres se incorporen y se mimeticen dentro del grupo. No obstante, estas confluencias se intensificaron conforme al paso de los años, pues los mismos contextos históricos de las décadas del 80 y 90 influenciaron considerablemente las estructuras tradicionalistas y esencialistas que marcaban en ésa época a las culturas indígenas. Es así como estas comunidades incursionaron y se familiarizaron con este ambiente lleno de factores como la migración, la modernización, el comportamiento de los mercados tanto nacionales como internacionales, los que son en gran medida los responsables del dinamismo y los flujos culturales presente de estos tiempos. Estas circunstancias que dan cuenta que la confluencia de distintos actores: profesionales, entidades gubernamentales, entidades sin ánimo de lucro, comerciantes, etc. conjugados con las habilidades y destrezas de los artesanos, inmersos en una sociedad dinámica han provocado cambios a nivel productivo (evidenciadas en el sombrero vueltiao) que forman parte de las mutaciones de las costumbres culturales.

Sobre este punto, se abre un marco reflexivo donde que plantea interrogantes acerca de la conveniencia que representa para la etnia la implementación de toda esta estructura de planificación racional que concibe orientaciones hacia lo innovador, lo competitivo y lo comercial, dirigiendo el debate hacia cuestiones que evalúen la ejecución de estos procesos en términos de irrupción o manipulación del sistema sociotécnico perteneciente a una población artesana y analizar hasta qué punto su alineación a las demandas del mercado 
y el capital, les ha servido como estrategia que mejore y garantice su calidad de vida y supervivencia. Estos cuestionamientos incitan a reflexionar si realmente son estos los mecanismos adecuados para cuidar todo su circuito o si es imperativo pensar en nuevas formas de intervención que labren un futuro prometedor y duradero para ellos.

El camino hacia futuros prometedores se inicia considerando la necesidad de ampliar la mirada y el foco de atención hacia problemáticas complejas o intrincadas (wicked problems). De esta manera, se identificarían para poder ser comprendidas y manejadas dentro de su campo, con un nivel de acción más profundo que supere a las pragmáticas soluciones de causa y efecto, y se empiece a indagar y vincular estrategias a nivel sistémico y de transformación cultural que generen respuestas coherentes y duraderas, apropiadas a tiempos de transición.

\section{Notas}

1. Trocha, Paola (2017). Las artesanías Zenú: transformaciones y continuidades como parte de diversas estrategias artesanales. Fecha de presentación a examen: Agosto 2 de 2017. Universidad de Palermo. Buenos Aires, Argentina.

2. Departamento Administrativo Nacional de Estadística, DANE. 2005.

3. Diagnóstico del sector artesanal levantado como información de línea de base para el Sistema de Información Estadístico de la Actividad Artesanal, SIEAA. Abril de 2016, Colombia.

4. Doctora en Historia y Teoría de las Artes por la Facultad de Filosofía y Letras de la UBA, docente e investigadora en la cátedra de Arte Precolombino de esa institución, donde también ejerce la docencia de posgrado, y Profesora de Arte Amerindio en la Maestría en Historia del Arte del IDAES/UNSAM.

5. Doctora en Filosofía y Letras de la Universidad de Zaragoza.

6. Dickie se refiere al mundo del arte como ese espacio donde se crea arte, y que involucra a artistas como personas individuales o grupos que interactúan con ese mismo mundo.

7. Realizó estudios en la Universidad de Córdoba, Buenos Aires y La Plata; y en el Seminario Mayor (filosofía y letras; historia; filología; arqueología y antropología).Además realizó y dictó cursos de cerámica.

8. Dirección de Impuestos y Aduanas Nacionales de Colombia, DIAN.

9. Oxfam es una confederación internacional formada por 17 organizaciones no gubernamentales nacionales que realizan labores humanitarias en 90 países. Su lema es: "trabajar con otros para combatir la pobreza y el sufrimiento".

\section{Referencias}

Álvaro Zamora, M. (1996). Introducción general al arte. Arquitectura, escultura, pintura, artes decorativas: Artes decorativas. Madrid: Editorial Itsmo.

Artesanías de Colombia (1998). Manual del área de diseño, Unidad Bogotá.

Australian Public Service, ASP (2007). Tackling Wicked Problems. A public policy perspective. 
Baron, G. (2018). La transición urbana y social hacia un paradigma de movilidad sostenible. Cuadernos del Centro de Estudios en Diseño y Comunicación. Diseño en Perspectiva-Diseño para la transición. Número 80,153-172.

Barthes, R. (1993). La aventura semiológica. Barcelona: Editorial Paidós.

Barrera, G. y Quiñones, A. (2006). Conspirando con los artesanos. Crítica y propuesta al diseño en la artesanía. Bogotá: Editorial Pontificia Universidad Javeriana.

Baudrillard, J. (1978). Cultura y Simulacro. Barcelona: Editorial Kairós.

Bauman, Z. (2002). Modernidad Líquida. Buenos Aires: Fondo de Cultura Económica.

Benedetti, C. (2014). La diversidad como recurso. Producción artesanal Chané destinada a la comercialización e identidad. Buenos Aires: Editorial Antropofagia.

Berdugo Palma, L. (2009). Herencia Zenú. Barranquilla: Altiva Editores.

Bertucci, A. (2013). Sobre la Industria cultural. Horkheimer y Adorno. Problemas filosóficos contemporáneos. Cuaderno de cátedra. Perspectivas sobre filosofía, arte y comunicación. Comp. Analía Melamed. Cuadernos de cátedra de la Facultad de Periodismo y comunicación social de la UNLP. ISBN 978-950-34-1051-6. Noviembre 2013

Bourdieu, P. (2002). La Distinción. Criterios y Bases Sociales del Gusto. México: Ediciones Taurus

Bovisio, M. (2002). Algo más sobre una vieja cuestión: Arte ¿vs? Artesanías. Argentina: FIAAR, Fundación para la investigación del Arte Argentino.

Bustos Flores, C. (2009). La producción artesanal. Visión gerencial, 37-52. Recuperado de http://www.redalyc.org/articulo.oa?id-465545880009

Calvera, A. (2004). Arte ¿ Diseño. Barcelona: Editorial Gustavo Gil

Chiapponi, M. (1999). Cultura social del producto. Nuevas fronteras para el diseño industrial. Buenos Aires: Ediciones Infinito

Di Bella, D. (2018).Impacto de la experiencia Diseño en Perspectiva. Cuadernos del Centro de Estudios en Diseño y Comunicación. Diseño en Perspectiva-Diseño para la transición. Número 80, 173-239.

Dhale, C. (2015). Designing for Systems Change. Recuperado de https://vimeo.com/124062312

Dickie, G. (1997). El círculo del arte. Una teoría del arte. Traducción de The Art Circle. A Theory of Art por Sixto J. Castro (2005). Barcelona: Editorial Paidós.

Escobar, A (2017). Diseño para las transiciones. En: Etnografías contemporáneas 3, №4 pp. 32-63. Buenos Aires: IDAES-UNSAM.

Fajardo, D. (Noviembre, 2014). Estudio sobre los orígenes del conflicto social armado, razones de su persistencia y sus efectos más profundos en la sociedad colombiana. Universidad externado de Colombia. P. 1-55

Fernández Chiti, J. (2003). Artesanía, folklore y arte popular. Buenos Aires: Editorial Condorhuasi.

Fries Martínez, A. (2016). Desarrollo social y comercial del sector artesanal: Comunidades Wayúu, Zenú y Chamba. Seminario Iberoamericano de Artesanías: Lima

Fundación Economía Circular. (s.f). Economía Circular. Apoyar el cambio hacia una economía eficiente en el uso de los recursos. Recuperado de https://economiacircular.org/ wp/?page_id $=62$

García Canclini, N. (1989). Culturas híbridas. Estrategias para entrar y salir de la modernidad. México: Editorial Grijalbo. 
García Canclini, N. (1989). Las culturas populares en el capitalismo. México: Editorial Nueva Imagen.

Gay, A. y Samar, L. (2007). El diseño industrial en la historia. Córdoba: Ediciones Tec.

Guzmán, Á. y García, F. (2010). Diseño, Artesanía e Identidad. Experiencias académicas y locales de Diseño Artesanal en Colombia y El Salvador. Popayán: Ediciones Axis Mundi.

Irwin, T. (2012). Wicked Problems and the Relationship Triad. [Problemas intrincados y la relación triádica]. "Grow Small, Think Beautiful: Ideas for a Sustainable World from Schumacher College," Floris Books.

Irwin, T. (Julio, 2014). Transition Design: Design-Led Societal. Transition To More Sustainable Futures. En Congreso Latinoamericano de Diseño, Buenos Aires.

Jaramillo, A. (2007). Artesanía diseñada o diseño artesanal. En Encuentro Latinoamericano de Diseño. (2do, Buenos Aires). Trabajo presentado (acta 4, 103-104). Buenos Aires

Jaramillo, S. y Turbay, S. (2000). Internet, Los indígenas Zenúes. Geografía humana de Colombia, Región Andina Central.3(4). Instituto Colombiano de Cultura Hispánica. Bogotá.

Kossoff, G. (2018). Localismo cosmopolita: la red planetaria de la vida cotidiana dentro de lo local. Cuadernos del Centro de Estudios en Diseño y Comunicación. Diseño en PerspectivaDiseño para la transición. Número 73,51-66.

La estrategia de despojo de tierra de los hermanos Castaño. (2014,14 de febrero) Verdad Abierta.

Larraín, A. (2014). Los indígenas Zenú y la educación propia. Entre la "ausencia” de una lengua tradicional y la reivindicación de otros marcadores étnicos. Revista Digital do Instituto Latino-Americano de Arte, Cultura e História, 3, 1-17.

Lauer, M. (1981). Artesanos, Artesanía e Industria. Tomado de: http://hdl.handle. net/10625/23537

Levis, D. (2011). Del pigmento al Bit. Buenos Aires.

Lockton, D. y Stuart, C. (2018). Un vocabulario para las visiones del diseño para las transiciones. Cuadernos del Centro de Estudios en Diseño y Comunicación. Diseño en PerspectivaDiseño para la transición. Número 73, 27-49.

Margolin, V. (2007). Design, the Future and the Human Spirit. Design Issues, 23 (3), 4-15.

Meadows, D. (1999). Leverage Points: Places to Intervene in a System. Recuperado el 04/06/2017. Disponible en: http://donellameadows.org/archives/leverage-points-placesto-intervene-in-a-system/

Monserrate, R. y Serrano, D. (2016). Diagnóstico del sector artesanal y las particularidades regionales en Colombia, artesanías en barro de Chamba, filigrana y caña flecha". Estadística e información Artesanías de Colombia.

Mora, Y. (1974). Bases culturales en la enseñanza del diseño artesanal. Asociación colombiana de diseño artesanal y Artesanías de Colombia S.A. p 53-63

Mouchreck, N. y Krucken, L. (2018). Diseño como agente de cambio: iniciativas orientadas a la práctica en la enseñanza de diseño. Cuadernos del Centro de Estudios en Diseño y Comunicación. Diseño en Perspectiva-Diseño para la transición. Número 80, 123-138.

Oittana, L. (2013). La desaparición de lo real o el éxtasis de la comunicación. La Trama de la Comunicación, 17, 255-269.

Ortega y Gasset, J. (1998). El mito del hombre allende la técnica. Teorema: Revista internacional de filosofía, 7, 617-624. 
Pacheco Contreras, J.; Gómez Vásquez, G. \& Barrero Tapias, G. (2009). El desafío de las comunidades artesanales rurales: una propuesta ecotecnológica para una artesanía sostenible. Acta Agronómica, 58 (3),206-220.

Plazas, C.; Falchetti, A.; Van Der Hammen, T. y Botero, P. (1988). Internet, Cambios ambientales y desarrollo cultural en el bajo río San Jorge. Boletín museo del oro, 20,54-88.

Puche Villadiego, B. (Noviembre, 1981). La hicotea, totem del cultivo del maíz en el Sinú. 1,34-38

Puche Villadiego, B. (2001). El Gran Imperio Zenú. Centro de ingenieros hidráulicos y orfebres de filigrana fina en la América Hispánica. Montería: Editorial Tinta y Papel.

Quiñones, A.C. (2003). Reflexiones en torno a la artesanía y el diseño en Colombia. Bogotá: Centro Editorial Javeriano.

Ramos, A. (1992). El indio hiperreal. Serie Antropologia .135. Brasilia

Roca, G. (2011). La Sociedad Digital. [VIDEO]. Galicia. Disponible en: http://youtu.be/ kMXZbDT5vm0

Rotman, M.; Radovich, J. C. y Balazote, A. (2007). Pueblos originarios y problemática artesanal: Procesos productivos y de comercialización en agrupaciones Mapuches, Guaraní/ Chané, Wichís, Qom/Tobas y Mocovíes. Córdoba: Centro de Estudios Avanzados.

Santos, J. (2008). Nuevas pautas de consumo. Recuperado el 01/10/2015. Disponible en $\mathrm{http}: / /$ issuu.com/jksantos/docs/juan_carlos_santos_2008_-nuevas_pau

Scatolini, J. (2011). El pasaje del hombre de la sociedad moderna a la posmoderna. Anales, $41,338-346$

Stang, S. (2017, 04 de junio). Diez claves para encontrarle la vuelta a la economía circular. La Nación.

Tatis, G. (2013, 10 de marzo). Una historia trenzada. Universal p. 6-7.

Universia (2016) El sombrero Vueltiao: origen, historia y tradición. (2016, 25 de abril)

Uribe Becerra, M (s.f). Personalización: producto e individualidad

Van Dommelen, D (Agosto, 1972). Las artesanías en Colombia. En Graciela Samper de Bermudez (gerente general). Primer seminario sobre diseño artesanal en Colombia. Seminario dirigido por el Ministerio de Desarrollo Económico y Artesanías de Colombia, Bogotá.

\begin{abstract}
The vueltiao hat (cultural symbol of Colombia) has driven different researches at the ethnographic and anthropological levels that describe the social and cultural manifestations of the Zenú ethnic group. This work aims to increase the studies about artisanal production from the perspective of cultural flows and the constant dynamism of the present that condition and influence the transformations in the crafts that are produced. The analysis of these considerations, understood as part of dynamic social processes and transitions, tries to study a path of hat variations in response to different contexts, which have impacted their modes of production, consumption, meaning and survival.
\end{abstract}


Keywords: Social field - Native peoples - Socio-technical system - Handcraft Production - Vueltiao hat- Postmodernity - Hyperconsumption - Sustainability - Transition Design - Colombia.

Resumo: O chapéu vueltiao (símbolo cultural de Colômbia) tem gerado pesquisas etnográficas e antropológicas que descrevem as manifestações sociais e culturais da etnia Zenú. Este trabalho procura acrescentar os estudos sobre a produção artesanal desde a perspectiva dos fluxos culturais e o dinamismo constante da atualidade que condicionam e influem as transformações nos artesanatos que se produzem. A análise destas considerações, entendidas como parte de processos e transições sociais dinâmicas, procura estudar um percurso das variações do chapéu vueltiao em resposta aos diferentes contextos, que impactaram nos modos de produção, consumo, significação e supervivência.

Palavras chave: âmbito social - povos originários - sistema sócio-técnico - produção artesanal - chapéu vueltiao - pós modernidade - hiperconsumo - sustentabilidade - design para a transição - Colômbia. 